\title{
The Expanded Debate over the Future of the Regulatory State
}

\author{
Thomas O. McGarity†
}

If the regulatory state is at a crossroads, it is because the winners of the 1994 elections have elevated the usually dry topic of federal regulation to a highly visible status. During the summer of 1995, the prominence in the news media of articles and editorials about cost-benefit analysis, risk assessment, scope of judicial review, and regulatory budgets caused twinges of excitement in the normally leaden breasts of public policy wonks; these self-styled experts then raced to Capitol Hill in droves to testify on the virtues and limitations of this or that species of regulatory reform. Following the hearings, members of Congress took to the floor with fancy props to debate esoteric language designed to change fundamentally the way federal agencies do business.

The primary significance of the 1994 elections for the continuing debate over the role of regulation in society has been to reopen previously settled questions and to revive positions that have remained virtually dormant since the New Deal. Congress is now within a vote or two of enacting radical changes to the Administrative Procedure Act that would significantly affect both the pace and substantive content of federal regulation. Also on the table are radical changes to environmental statutes, occupational safety and health laws, banking regulation, and legal protections against employment discrimination. These have not been especially attractive developments for those (often among the beneficiaries of existing regulatory programs) who believe that government has an important role to play in a robust capitalist economy and who would not welcome a return to the moral and legal regime of late nineteenth-century America. Although defenders of the federal regulatory bureaucracy are rarely featured on the evening news or the radio talk shows, the programs that the much reviled bureaucrats administer provide a crucial protective shield against the misery and waste that always accompany the abuse of private power.

$\dagger$ W. James Kronzer Chair in Trial and Appellate Advocacy, University of Texas School of Law. 
This Essay proffers two foundational ideas in Part I: (1) Congress enacted most of the existing federal regulatory statutes to protect some citizens from the adverse consequences of the conduct of others; and (2) the rationales for these protections go beyond the "broken market" explanation offered by many regulatory reformers as the appropriate basis for government intervention into private arrangements. Rejecting the contention that the 1994 elections reflect a paradigm shift among the general public on the subject of federal regulation, Part II places the current expanded debate in historical perspective by briefly relating the history of regulation and regulatory reform. Part III then turns to the debate itself and sorts the participants into five broad categories: the radical anti-interventionists, the free marketeers, the modern mugwumps, the good government reinventionists, and the unrepentant protectionists. In describing the characteristics of each camp, this Part attempts to convey a sense of the nature and complexity of the current debate. Finally, Part IV speculates on how the debate is likely to be resolved in the near term.

\section{Regulation as Protection}

The impetus behind most federal regulatory programs has been a demand by ordinary citizens for protection from the adverse consequences of the conduct of other citizens acting individually or (more often) collectively through corporations and other economic entities. ${ }^{1}$ An administrative regulatory regime is not the only vehicle available to government for protecting some of its citizens from the conduct of others. Criminal codes, for example, usually address conduct that most citizens know to be wrong. The common law of torts indirectly protects individuals by making it clear in advance that persons engaged in some kinds of activities will have to compensate persons who are harmed thereby. Self-help also may be available to an individual who believes that he or she is entitled to protection from another's activities and has the wherewithal to provide that protection. However, the failure of these alternatives to successfully protect citizens from

1 Not all regulatory programs were created to protect the weak from the powerful. In a democratic society, legislatures are constantly bombarded by appeals from citizens who would extract private economic gains from ostensibly protective legislation. Some cynical opponents of government regulation would place most, if not all, regulation in this category. While some regulation exists primarily to protect private cartels, I believe that it constitutes a small and diminishing proportion of all federal regulation. 
others has led to the continuous evolution of federal regulatory programs over the last century.

Beginning with the Interstate Commerce Commission in 1887, Congress has created several regulatory regimes in which agencies protect citizens from abusive and discriminatory practices of monopolies and cartels by establishing rates, allocating routes, and providing standards for quality of service. ${ }^{2}$ Although Congress has relied for the most part upon self-help to address misleading and abusive business practices outside of monopolistic contexts, it has recognized that self-help is not an adequate remedy in many cases. The Securities and Exchange Commission ("SEC"), the Commodity Futures Trading Commission, and the Federal Trade Commission ("FTC") all regulate the terms and conditions of certain contractual relationships to ensure that poorly informed consumers are not duped by unscrupulous sellers. Finally, Congress has recognized that some economic relationships naturally give rise to the potential for abuse because of the unequal bargaining power of the participants. For example, since individual employees rarely have the power to bargain with large employers over terms and conditions of employment, the National Labor Relations Act allows employees to bargain collectively with employers and establishes the ground rules for the exercise of employer and collective employee power. ${ }^{3}$

With the enactment of the Federal Food and Drugs Act of $1906,{ }^{4}$ Congress began to protect citizens from business practices that posed unacceptable health and safety risks. Since then, Congress has empowered agencies like the Food and Drug Administration ("FDA"), the Environmental Protection Agency ("EPA"), and the Occupational Safety and Health Administration ("OSHA") to remove unhealthful or dangerous products from the market and to promulgate standards to ensure food quality and

2 See generally Robert E. Cushman, The Independent Regulatory Commissions 37416 (Oxford 1941) (detailing the development and operation of regulatory commissions from 1887 through the New Deal).

3 Government intervention for this purpose involves a careful balancing process. In addition, government power aimed at equalizing private bargaining power can be manipulated by private individuals to empower them to harm others. For example, labor unions have historically been some of the worst purveyors of unfair employment practices. See, for example, David E. Bernstein, Roots of the 'Underclass': The Decline of Laissez-Faire Jurisprudence and the Rise of Racist Labor Legislation, 43 Am U L Rev 85, 91-96 (1993) (chronicling the "Rascist [sic] History of American Labor Unions").

4 Pub L No 59-384, 34 Stat 768, codified at 21 USC $\$ \S 1-15$ (1934), repealed by the Federal Food, Drug, and Cosmetic Act of 1938, § 902(a), Pub L No 75-717, 52 Stat 1040, 1059 , codified at 21 USC $\S 301$ (1994). 
protect the environment. Congress has also created regulatory programs to protect the interests of all citizens in common resources, like the radio frequency spectrum, endangered species, and pristine wilderness areas. ${ }^{5}$

During the last forty years, Congress has assigned a high priority to protecting victims of invidious discrimination. For example, unlike common law contract and tort litigation, Congress, not the courts, has established substantive regulatory requirements to govern litigation under statutes aimed at eliminating irrational discrimination on the basis of race, sex, religion, national origin, age, or disability. Congress has also established procedures to protect employees from being discharged for "whistleblowing," advocating a union, and engaging in other activities that advance the public interest. ${ }^{6}$

In the preceding description, I have carefully avoided employing "correcting for market failure" as a rationale for regulation. The academic literature on regulation and regulatory reform thrives on sophisticated theoretical analyses of market failure, regulatory mismatches, and techniques for fixing broken markets. ${ }^{7}$ Many academic regulatory reformers presume that unimpeded markets are the best way to allocate scarce resources and demand that any government intervention be justified as an effective corrective to some identified market failure. Although this "broken market" paradigm may be useful analytically for studying some kinds of regulation, it rarely explains why Congress enacted protective statutes.

When Congress enacted the Clean Water Act, the debates were not filled with talk about "externalities" and "spillovers."

5 Government regulation may be the only way to protect the shared interest of all citizens in having a common resource available. See Garrett Hardin, The Tragedy of the Commons, 162 Science 1243, 1245-48 (1968). At the same time, such regulation can empower some private entities to harm others. Allocating all of the available spaces in the radio frequency spectrum to stations that distribute racist propaganda, for example, could harm the minorities who are the victims of that sort of propaganda.

6 See, for example, Occupational Safety and Health Act of 1970, Pub L No 91-596, 84 Stat 1590, codified as amended at 29 USC $\$ 660$ (c) (1994); Age Discrimination in Employment Act of 1967, Pub L No 90-202, 81 Stat 602, codified as amended at 29 USC $\$ 623$ (1994); Toxic Substances Control Act of 1976, Pub L No 94-469, 90 Stat 2044, codified as amended at 15 USC $\S 2622$ (1994). See generally Cynthia L. Estlund, Wrongful Discharge Protections in an At-Will World, 74 Tex I Rev 1655 (1996).

7 For example, see generally Stephen Breyer, Analyzing Regulatory Failure: Mismatches, Less Restrictive Alternatives, and Reform, 92 Harv L Rev 547 (1979) (discussing all three approaches at length). Breyer asserts that "the most important justifications for government regulation of the economy are well described as instances of classical market failure." Id at 553. 
When the Occupational Safety and Health Act was debated, no congressperson stood up on the floor of the House to suggest that bargaining between employers and employees was distorted by the lack of communication of risk-related information. The supporters of the Clean Water Act and the Occupational Safety and Health Act related horror stories of fish kills, flaming rivers, horrible explosions, and debilitating workplace diseases. ${ }^{8}$ The congressional committees that considered these bills did not demand that advocates of federal regulation identify particular market failures and specify appropriate tools for fixing those failures. Instead, the impetus behind most regulatory programs has been concern about abuse of power by private individuals and corporations. Furthermore, the regulatory techniques adopted by Congress have generally been aimed at stopping the harm and bringing about a rapid end to the suffering, rather than at achieving the most efficient expenditure of private resources.

Similarly, the current debates over regulatory reform in Congress have been less about "regulatory mismatches" identified by supporters of the broken-market paradigm than about abuse of government power by unelected bureaucrats. The legislative debates during the summer of 1995 were filled with horror stories of small businesses being raked over the coals by abusive government inspectors and alleged regulatory stupidity in writing pointless or perverse regulations. ${ }^{9}$ In sum, past and present regulatory reformers have rarely focused on market failure as the basis of regulation.

B See, for example, Occupational Safety and Health Act of 1970, S Rep No 91-1282, 91st Cong, 2d Sess 3-4, reprinted in 1970 USCCAN 5177, 5179-80 (providing examples of brown lung in cotton textile workers, asbestosis and mesothelioma in asbestos workers, and pesticide poisonings in farm workers).

9 See, for example, Kay Bailey Hutchison, Federal Rules Must Make Sense, Dallas Morning News 5J (Feb 5, 1995) (relating story of construction company cited by OSHA when its employees failed to wear hard hats in an emergency attempt to save the life of a worker in a collapsed trench); Comprehensive Regulatory Reform Act of 1995, Hearings before the Senate Committee on the Judiciary, 104th Cong, 1st Sess (Mar 17, 1995) (statement of Senator Orrin Hatch) (relating story of bank that was required to put Braille keypads on drive-through automatic teller machines); Regulatory Transition Act of 1995, HR Rep No 104-39, 104th Cong, 1st Sess 9 (noting safety regulation requiring that buckets leak so as to prevent infant drowning). Many of the horror stories, including the leaking buckets, were either untrue or grossly misleading. See Comprehensive Regulatory Reform Act of 1995, S Rep No 104-90, 104th Cong, 1st Sess 154-55 (supplemental views of Senator Leahy). 


\section{REGULATION AND REACTION}

The regulatory programs described above were enacted only after fierce political battles between advocates of protective governmental action and advocates of free markets. Indeed, the modern regulatory state emerged out of the extraordinary efforts to address the social catastrophe of the Great Depression. ${ }^{10}$ For many observers, the progressive forces favoring government intervention achieved a nearly irreversible victory during the New Deal years, which, in their view, represented a critical turning point in American history not unlike the emergence of the Constitution out of the Articles of Confederation and the emergence of a powerful federal government out of the ashes of the Civil War during the Reconstruction period.

Professor Bruce Ackerman has characterized the New Deal shift in conventional wisdom concerning the proper role for government as a "constitutional moment." With that shift, "the New Deal Democrats amended the Constitution by provoking a complex constitutional dialogue between the voters at large and institutions of the national government, a dialogue that ultimately substituted for the more federalistic processes of constitutional revision detailed in Article Five." ${ }^{\prime 11}$ Yet, at the same time that Professor Ackerman's "dualistic" analysis affords a special permanence to the regulatory state, it also suggests that other transformative experiences are waiting to happen, and indeed may be happening at this moment. ${ }^{12}$ In examining the regulato-

${ }^{10}$ Congress had enacted several important regulatory programs prior to the New Deal, but they did not intrude greatly into private economic arrangements, and the intrusions were usually limited to particular industries. See Thomas O. McGarity, Regulatory Reform and the Positive State: An Historical Overview, 38 Admin L Rev 399, 400-01 (1986).

11 Bruce Ackerman, Constitutional Politics/Constitutional Law, 99 Yale L J 453, 459 (1989). Professor Ackerman's ambitious undertaking is not without its critics. For example, see generally William W. Fisher, III, The Defects of Dualism, 59 U Chi L Rev 955 (1992); Frank Michelman, Law's Republic, 97 Yale L J 1493, 1519-24 (1988) (characterizing Professor Ackerman's approach as "authoritarian constitutional jurisprudence"); Cass R. Sunstein, Legislative Foreword: Congress, Constitutional Moments, and the Cost-Benefit State, 48 Stan L Rev 247, 253-54 \& n 23 (1996) (recognizing the New Deal as a "constitutional moment," but only in a metaphorical sense-a metaphorical moment, so to speak).

12 See Bruce A. Ackerman, Transformative Appointments, 101 Harv L Rev 1164, 1178 (1988) (acknowledging the possibility of another "constitutional moment" during the Reagan administration, but citing the failure of the Senate to confirm Robert Bork as evidence that it did not occur). Professor Michelman likens Professor Ackerman's constitutional moments to Thomas Kuhn's "paradigm shifts" in the context of the evolution of scientific thought. Michelman, 97 Yale $\mathrm{L}$ J at 1522-23 (cited in note 11). See also Thomas S. Kuhn, The Structure of Scientific Revolutions (Chicago 1962). 
ry state at a crossroads, it may be appropriate to ask whether the United States is currently engaged in similar "higher lawmaking" in which "We the People"13 are speaking once again. Certainly the winners of the 1994 elections would like to think that the regulatory reform statutes they plan to enact during the next few years "represent the considered judgment of a mobilized majority of American citizens." 14 Professor Sunstein, for one, welcomes this possibility with unconcealed enthusiasm. ${ }^{15}$

Professor Ackerman might respond that the current conservative Republican ascendancy reflects merely a public reaction to, and partial rejection of, the civil rights-public interest movement of the activist 1960s and not a fundamental rejection of the New Deal regulatory state. In this view, the proponents of activist government went too far: in protecting health, safety, and the environment past the point at which costs equalled benefits; in pampering consumers; and in pushing government's approach to civil rights beyond protection to affirmative action and mandatory accommodation. For Ackerman, the regulatory state bequeathed by the New Deal is, at its core, alive and well. Liberals and conservatives alike still accept the basic New Deal principles, and the regulatory reformers mean only to restore a sense of balance.

This benign view of the objectives of the regulatory reformers since the election of Ronald Reagan in 1980 is, in my view, fundamentally at odds with the facts. Many conservative advocates of regulatory reform have in mind a full-scale return to the business-oriented, laissez-faire principles that dominated this country during the last quarter of the nineteenth century. Their lobbyists and their more moderate allies in Congress may urge caution and compromise at any particular juncture, but the overall goal is to wipe out the legislative legacy, not only of the Sixties, but also of previous waves of activist government, including the New Deal. ${ }^{16}$

13 Bruce Ackerman, 1 We the People 7-8 (Belknap 1991).

14 Ackerman, 99 Yale L J at 464 (cited in note 11) (noting that the dualist denies that all statutes that gain a legislative majority in Washington represent the considered judgment of a mobilized majority). Of course, few of the conservative victors of the 1994 elections would agree with Ackerman's "constitutional moment" thesis in the first place.

${ }_{15}$ Sunstein, 48 Stan L Rev at 257 (cited in note 11).

${ }^{16}$ See James Allen Smith, The Idea Brokers: Think Tanks and the Rise of the New Policy Elite 22 (Free Press 1991) ("The conservative revolt was really a frontal assault on the pragmatic philosophical assumptions that have been at the core of American politics ... since the turn of the century."). See also id at 220-23 (describing the agenda of leading conservative libertarian think tanks). 
To gain a glimpse of the future envisioned by many regulatory reformers, we must travel backward past the New Deal and the Progressive Era to the last quarter of the nineteenth century. Like Professor Ackerman, I view the Reconstruction period as profoundly important for American political history, but for different reasons. Its importance lies in two developments, neither of which grew directly out of the Reconstruction Amendments and associated implementing legislation. First, the conclusion of the Civil War marked the end of the transformation of the American economy from a mercantile/agrarian economy to an aggressive financial/industrial economy. Second, at all levels of government, the laissez-faire principle became the dominant theory of social welfare. Under the banner of laissez-faire, huge private enterprises were assembled and destroyed, and mountains and deserts were conquered and despoiled. Poor immigrants and former slaves, working for subsistence wages, built the railroads, labored at the factories, and dug the mines that powered an enormous economic expansion, ${ }^{17}$ and they were injured and killed by the hundreds in the process. ${ }^{18}$ Seventy-two-hour work weeks were not uncommon when business was good, and wage cuts and layoffs were inevitable when the economy turned sour. ${ }^{19}$

The laissez-faire principle also extended to the businessgovernment interface. Public officials and legislators were enriched by business opportunities and outright bribes proffered by the great financiers and industrialists of the time. ${ }^{20}$

Despite the increasingly evident human and ecological devastation brought about by excessive greed and corruption, little action was taken at either the state or the federal level. When some states began to exercise their powers to protect the victims of runaway industrialization, the Supreme Court, steeped in laissez-faire ideology, struck their efforts down. ${ }^{21}$ At the federal

17 The United States economy grew during the last quarter of the nineteenth century by almost every conceivable measure-overall production of goods and services, output per man hour, value of land, and overall wealth. See Ray Ginger, Age of Excess: The United States from 1877-1914 90-92 (Macmillan 2d ed 1975).

${ }_{18}$ See Matthew Josephson, The Robber Barons: The Great American Capitalists 18611901 ch 4 (Harcourt 1934).

19 Ginger, Age of Excess at 57 (cited in note 17).

${ }_{20}$ John M. Blum, et al, The National Experience: A History of the United States 420, 422-23 (Harcourt Brace Jovanovich 1963) (Central Pacific Railroad principal, Collis Huntington, "talked about bribing and buying congressmen as he would about the purchase of so many cattle."); Josephson, Robber Barons at 84, 222-23 (cited in note 18) ("The passage of a bill involved 'arguments' in the form of considerable sums of cash.").

${ }^{21}$ See, for example, Wabash, St. Louis and Pacific Railway Co. v Illinois, 118 US 557, 
level, a modest reform effort by well heeled members of the East Coast establishment calling themselves Liberal Republicans (and later branded "Mugwumps") placed some limitations on governmental graft and corruption, but in the private sector these reformers did not challenge the underlying principle of laissezfaire. ${ }^{22}$ If any point in time is entitled to elevation to quasi-constitutional status, it might easily be the defeat of emerging populist movements in the elections of 1894 and 1896. These elections ratified the previous ascendancy of laissez-faire and ushered in an early twentieth-century political culture in which concentrated economic power remained largely unchecked. ${ }^{23}$

This period in American history is, in my opinion, exceedingly important because it established a baseline of economic freedom and government largesse to which powerful business entities, their allies in academia and think tanks, and the neo-muckrakers of the conservative media persistently return. As each wave of reform crested during the twentieth century, the Chamber of Commerce, the National Association of Manufacturers, the Farm Bureau, and countless other trade associations and business concerns did their best to defeat it. When Congress nevertheless enacted reform, these groups did everything within their power to resist bureaucratic and judicial implementation. And finally, when all other attempts at blocking reform failed, these same interests tacitly sanctioned disobedience or sought relief in the legislature. In each of these battles, their pleas were cast as appeals to objectivity, efficiency, common sense, and due process, but the goal was always the same: a return to the laissez-faire baseline of the late nineteenth century. ${ }^{24}$

This is history viewed as a cycle of reform, resistance, and reaction-swinging like a pendulum, but like a pendulum attached at its apex to a point that is itself lurching forward and

575-77 (1886) (declaring unconstitutional an Illinois statute penalizing discriminatory railroad freight rates).

${ }_{22}$ See Earle Dudley Ross, The Liberal Republican Movement 238 (Henry Holt 1919); Gerald W. McFarland, ed, Moralists or Pragmatists? The Mugwumps 1884-1900 2 (Simon \& Schuster 1975).

${ }^{23}$ See Blum, et al, National Experience at 493 (cited in note 20) (McKinley's victory in 1896 "meant a return to conservatism and another businessman's regime."); John L. Thomas, Alternative America: Henry George, Edward Bellamy, Henry Demarest Lloyd and the Adversary Tradition 334 (Belknap 1983) ("The election of 1896 proved beyond question that the forces of corporate capitalism that were revolutionizing the rest of American life had now triumphed at the polls.").

${ }^{24}$ See William Greider, Who Will Tell the People?: The Betrayal of American Democracy 56-58 (Simon \& Schuster 1992). 
backward. In this view, the New Deal is not transformative; it merely represents a point at which the reforms were especially aggressive, the resistance was fairly timid, and the reactions took longer than usual to have an impact. The business community by no means accepted the regulatory state as a new baseline after the New Deal. They resisted it first in court, where they initially achieved some notable victories. ${ }^{25}$ After the "switch in time" left a majority of the Supreme Court willing to accept activist government, ${ }^{26}$ the business community continued to react, but with no prospect of substantive victory in the political sphere, it was content to harness the New Deal procedurally through the Administrative Procedure Act ("APA"). ${ }^{27}$ Finally, when one of the most powerful of the New Deal agencies, the National Labor Relations Board, began to flex its muscles on behalf of organized labor, reformers were able to stimulate enough legislative sympathy to reign in that agency through the enactment of the TaftHartley Act. ${ }^{28}$

The pendulum began to swing back again in the mid-1960s and the 1970s with the advent of the civil rights-public interest movement. Title VII of the Civil Rights Act of $1964^{29}$ and subse-

25 See, for example, United States $v$ Butler, 297 US 1, 68-78 (1936) (declaring the Agricultural Adjustment Act unconstitutional); A.L.A. Schechter Poultry Corp v United States, 295 US 495, 542-51 (1935) (declaring portion of the National Industrial Recovery Act unconstitutional); Panama Refining Co. v Ryan, 293 US 388, 414-33 (1935) (invalidating $\S 9$ (c) of the National Industrial Recovery Act). See also Peter Irons, The New Deal Lawyers 71-72, 100-02, 142-43, 150, 153, 192-95, 246-47, 249-52 (Princeton 1982); Michael Comiskey, Can a President Pack-or Draft-the Supreme Court?: FDR and the Court in the Great Depression and World War II, 57 Albany L Rev 1043, 1045-46 \& n 21 (1994) (reporting that "[i]n the three terms from 1933-34 to 1935-36, the Court struck down or limited New Deal measures in eleven of thirteen cases"); Clyde P. Weed, The Nemesis of Reform: The Republican Party during the New Deal 171 (Columbia 1994).

${ }_{26}$ See Comiskey, 57 Albany L Rev at 1046-47 (cited in note 25).

27 McGarity, 38 Admin L Rev at 402-07 (cited in note 10).

28 Labor Management Relations Act of 1947, Pub L No 80-101, 61 Stat 136, codified as amended at 29 USC $\S \S 141-87$ (1994). See Universal Camera Corp $v$ NLRB, 340 US 474,487 (1951) (concluding that the Taft-Hartley Act mandated the same scope of judicial review as the APA). Professor Estlund relates:

With the growing success of labor during and after World War II, and particularly following a wave of strikes after the war ended, employers gained a more sympathetic hearing for their complaints that unions were "abusing" their economic power, and that the Board was biased in favor of unions affiliated with the national federations, especially the militant Congress of Industrial Organizations, whose growth the Wagner Act helped facilitate.

Cynthia L. Estlund, Economic Rationality and Union Avoidance: Misunderstanding the National Labor Relations Act, 71 Tex L Rev 921, 977 n 212 (1993).

${ }_{29}$ Pub L No 88-352, 78 Stat 241, codified as amended at 42 USC $\S 2000$ e to $2000 \mathrm{e}-17$ 
quent amendments reaffirmed the federal role in protecting the descendants of slaves from irrational discrimination in employment and boldly asserted a new role for the federal government in protecting women, the aged, and the disabled from such discrimination as well. ${ }^{30}$ During this time, Congress enacted additional fundamental changes to the regulatory state, including the landmark Occupational Safety and Health Act of $1970,{ }^{31}$ and foundational statutes for modern environmental law. ${ }^{32}$ Congress also attempted to revitalize the moribund FTC with the Magnuson-Moss Warranty-Federal Trade Commission Improvement Act, ${ }^{33}$ to protect consumers from dangerous products with the Consumer Product Safety Act of $1972,{ }^{34}$ and to protect employee pensions from unscrupulous employers with the Employee Retirement Income Security Act of $1974{ }^{35}$

In addition to favoring a more active federal government, these statutes also differed from their predecessors in the means they employed to attain those protections. Most of these new statutes expressed a clear preference for federal policy making through the little used tool of informal rule making. Because of the relative ease with which regulatory agencies could promulgate binding rules, the use of that regulatory tool had the potential to change a much broader range of private conduct much more rapidly than the use of traditional adjudicatory approaches. In contrast to previous statutes, the new statutes specified more

(1988 \& Supp 1993).

30 See Age Discrimination in Employment Act of 1967, Pub L No 90-202, 81 Stat 602, codified as amended at 29 USC §§ 621-34 (1994); Americans with Disabilities Act of 1990, Pub L No 101-336, 104 Stat 327, codified as amended at 42 USC $\S \S 12101-213$ (1994).

${ }^{31}$ Pub L No 91-596, 84 Stat 1590, codified as amended at 29 USC $\S 651$ et seq (1994).

${ }^{32}$ Important environmental statutes enacted since the 1960s include the Clean Air Act, Pub L No 88-206, 77 Stat 392 (1963), codified as amended at 42 USC $\S \S 7401$ et seq (1988 \& Supp 1993), the Clean Water Act, Pub L No 95-217, 91 Stat 1566 (1977), codified as amended at 31 USC $\S \S 1251$ et seq (1994), the Federal Environmental Pesticide Control Act of 1972, Pub L No 92-516, 86 Stat 973, codified as amended at 7 USC $\S 136$ (1994), the Resource Conservation and Recovery Act, Pub L No 94-580, 90 Stat 2795 (1976), codified as amended at 42 USC $\S \S 6901$ et seq (1988 \& Supp 1993), and the Endangered Species Act of 1973, Pub L No 93-205, 87 Stat 884, codified as amended at 16 USC $\S \S 1531$ et seq (1994). See David Vogel, The "New" Social Regulation in Historical and Comparative Perspective, in Thomas $\mathrm{K}$. McCraw, ed, regulation in perspective 161-75 (Harvard 1981) (chronicling the development of recent safety and environmental regulation).

${ }_{33}$ Pub L No 93-637, 88 Stat 2183 (1975), codified as amended at 15 USC $\S$ 2301-12 (1994).

34 Pub L No 92-573, 86 Stat 1207, codified as amended at 15 USC $\S \S 2051-83$ (1994).

${ }_{35}$ Pub L No 93-406, 88 Stat 829, codified as amended at 29 USC $\S \S 1001$ et seq (1994). 
particular goals for agency regulatory programs and established particular deadlines for implementing them. Finally, unlike their predecessors, these statutes envisioned an active role for selfappointed representatives of the "public interest."

As soon as the newly created regulatory agencies began to promulgate the regulations needed to set these pervasive new programs in motion, the individuals, companies, and trade associations that had opposed their enactment began vigorously to resist their implementation. Unlike their tentative resistance to the New Deal regulatory programs, the resistance to the civil rights and public interest programs was swift and powerful. Presidents Nixon, Ford, and Carter all provided for interagency review of regulations issued by the major rule-making agencies. ${ }^{37}$ These reviews provided opportunities for allies of regulated businesses within an administration (usually from the Department of Commerce or OMB) to pressure the rule-making agency to soften the rules or to allow greater latitude for considerations of economic and technological feasibility. ${ }^{38}$ Occasionally, the regulated entities and their trade associations gained direct access to the otherwise secret internal review process and presented their arguments directly to administration policymakers. ${ }^{39}$

As regulations began to emerge from the agencies, the forum for industry resistance shifted to the reviewing courts. Virtually every rule of any consequence was challenged in court. Applying the "hard look" doctrine of substantive judicial review, the federal courts of appeals began to remand important rules because

${ }^{36}$ See Richard J. Pierce and Sidney A. Shapiro, Political and Judicial Review of Agency Action, 59 Tex L Rev 1175, 1179 (1981); Richard B. Stewart, The Reformation of American Administrative Law, 88 Harv L Rev 1667 (1975).

${ }^{37}$ The focal point for interagency review shifted with time from the Department of Commerce, to OMB, to the Council on Wage and Price Stability, to an entity called the Regulatory Analysis Review Group, and then back to OMB. See Thomas O. McGarity, Reinventing Rationality: The role of regulatory analysis in the federal bureaucracy 17-25 (Cambridge 1991).

${ }^{33}$ See id at ch 19; Oliver A. Houck, President $X$ and the New (Approved) Decisionmaking, 36 Am U L Rev 535, 539-44 (1987); Erik D. Olson, The Quiet Shift of Power: Office of Management \& Budget Supervision of Environmental Protection Agency Rulemaking Under Executive Order 12,291, 4 Va J Nat Resources L 1, 40-71 (1984).

${ }^{3}$ See, for example, Sierra Club v Costle, 657 F2d 298, 384-408 (DC Cir 1981) (rejecting Environmental Defense Fund's claim that the EPA was improperly influenced by the coal industry's "ex parte blitz"). See also Alan B. Morrison, OMB Interference with Agency Rulemaking: The Wrong Way to Write a Regulation, 99 Harv L Rev 1059, 1068 (1986) (suggesting that industry has input into OMB's decision whether to permit an agency to begin considering a problem in earnest).

40 See, for example, Greater Boston Television Corp v FCC, 444 F2d 841, 851 (DC Cir 1970), in which Judge Leventhal coined the term. 
the agencies had failed to provide adequate reasons for their resolutions of critical questions, because the agencies had failed to respond adequately to comments, and because the reasons given were judged to be arbitrary and capricious in light of the data and analysis in the record. ${ }^{41}$

Hearings before sympathetic congressional committees also provided forums for complaints about the stringency of agency regulations and the unanticipated economic consequences of their implementation. In response to the serious economic impact of the new programs and the economic turmoil of the successive energy "crises," companies, trade associations, and newly emerging conservative think tanks seized the mantle of reform and proposed legislation designed to force agencies to think more carefully about the economic impact of their regulations, to provide a statutory basis for the interagency review process, and to change the substance of the regulatory statutes to "avoid a mismatch between a particular need for governmental intervention and the regulatory method used to meet that need. ${ }^{342}$ Finally, after several economic regulatory agencies initiated bold experiments in economic deregulation without any noticeable adverse effects, Congress enacted legislation to eliminate some longstanding economic regulatory regimes. ${ }^{43}$

Thus, by the time Ronald Reagan assumed office in 1981, the pendulum had begun to swing back toward the laissez-faire views of the opponents of federal regulation; and with the election of Reagan, the reformers scored a partial victory. President Reagan, who could credit his election to an effective campaign against the federal bureaucracy, made "regulatory relief" one of the four primary goals of his "economic recovery program. ${ }^{\text {m4 }}$ Packed

41 See Robert L. Rabin, Federal Regulation in Historical Perspective, 38 Stan L Rev 1189, 1295-1315 (1986); Paul Verkuil, Judicial Review of Informal Rulemaking, $60 \mathrm{Va} \mathrm{L}$ Rev 185, 206 (1974).

${ }^{42}$ American Bar Association Commission on Law and the Economy, Federal Regulation: Roads to Reform 1 (ABA Exposure Draft 1978). The report of the Commission on Law and the Economy became a key document in the nascent regulatory reform effort. Its primary author, Harvard law professor Stephen Breyer, later published expanded versions of the report in the Harvard Law Review and as a book. Stephen Breyer, Regulation and Its Reform (Harvard 1982); Breyer, 92 Harv L Rev 547 (cited in note 7). See also Robert S. Smith, The Occupational Safety and Health Act 84-85 (AEI 1976); Eugene J. McAllister, ed, Agenda for Progress: Examining Federal Spending ch 5 (Heritage Found 1981); Jay Van Andel and Richard M. DeVos, The Government versus the Entrepreneur, Policy Rev 23, 28-32 (Fall 1979) (discussing "economic burden of excessive regulation" and urging reform, including economic impact statements and cost-benefit analysis).

43 See Martha Derthick and Paul J. Quirk, The Politics of Deregulation 1-28 (Brookings 1985).

4 See White House Report on the Program for Economic Recovery, 1981 Pub Papers 
within the beguilingly simple call for regulatory reform, however, was a broad range of proposals aimed at revamping the regulatory state. The most successful reform was the implementation named the "regulatory impact analysis" requirement, a cognitive regulatory reform aimed at changing agency thought processes. ${ }^{45}$ Building on the regulatory analysis efforts of the three previous administrations, President Reagan signed an executive order requiring all executive branch agencies to prepare a comprehensive analysis of the costs and benefits of alternative proposals for every major rule-making initiative. ${ }^{46}$ When not inconsistent with the agency's statute, the agency was obliged to choose the alternative with the greatest net benefits. ${ }^{47}$ Subsequent executive orders required agencies to analyze "just compensation clause," "federalism," and "family" impacts of regulations. ${ }^{51}$

The Reagan administration also achieved certain structural regulatory reforms-reforms aimed at structuring agency decision making so that different institutional actors played greater or lesser roles. ${ }^{52}$ President Reagan retained the interagency review process and designated the Office of Information and Regulatory Affairs in OMB as the focal point. The executive order gave OMB the authority to review all regulatory analysis documents for compliance with the executive orders' requirements. ${ }^{53}$ A later executive order gave $\mathrm{OMB}$ the task of coordinating all new regulatory initiatives and placing them on a comprehensive regulatory agenda. ${ }^{54}$ The Reagan administration also created a highly

Pres 116, 126-29.

4 McGarity, 38 Admin L Rev at 400 (cited in note 10). See also Thomas O. McGarity, Regulatory Reform in the Reagan Era, 45 Md L Rev 253, 256-60 (1986) (developing the typology at greater length).

${ }^{46}$ Exec Order No 12291 §§ 2-3, 3 CFR 127, 128-30 (1981).

47 Id $\S 2(e), 3 \mathrm{CFR}$ at 128.

48 Exec Order No 12630 \& 1, 3 CFR 554, 554-55 (1988).

49 Exec Order No 12612 § 1-3, 3 CFR 252, 252-54 (1987).

so Exec Order No 12606 §§ 1-2, 3 CFR 241, 241-42 (1987).

51 Furthermore, to meet these new analytical requirements, the agencies began to hire economists and policy analysts capable of drafting adequate regulatory analysis documents, and these employees and their different ways of viewing regulatory issues were over time absorbed into the cultures of the agencies. See McGarity, Reinventing Rationality at ch 1 (cited in note 37).

52 McGarity, 38 Admin L Rev at 400 (cited in note 10). See also McGarity, $45 \mathrm{Md} \mathrm{L}$ Rev at 256-60 (cited in note 45) (developing the typology at greater length).

53 Exec Order No 12291 \& 3, 3 CFR at 128-30 (cited in note 46).

54 Exec Order No $12498 \S \S 1-4,3$ CFR 323, 323-25 (1985). See McGarity, 38 Admin L Rev at 419-20 (cited in note 10) (summarizing requirements of Exec Orders Nos 12291 and 12498). 
visible Presidential Task Force on Regulatory Relief, chaired by Vice President George Bush, and charged it with resolving interagency disputes over proposals for new regulations and with pressuring the agencies to revisit existing rules that regulatees had identified as overly burdensome. ${ }^{55}$

The Reagan era of reform was not without its failures. An ambitious initiative by the administration and sympathetic Senators to codify the cognitive and structural reforms and to strengthen the procedural and judicial-review requirements of the APA died in the House. ${ }^{56}$ In addition, the administration's efforts to achieve substantive regulatory reform-attempts legislatively or administratively to change an agency's substantive output $^{57}$-were surprisingly unsuccessful. The administration initially pursued rapid substantive change by slashing agency budget requests and appointing inexperienced administrators who opposed federal regulation. ${ }^{58}$ The diligent efforts of some of these appointees to dismantle their agencies generated fierce opposition from the beneficiaries of regulation and their allies in Congress. After several widely reported scandals in the EPA precipitated intensive congressional investigations, the administration quietly abandoned this "destroy from within" strategy. Furthermore, agency attempts to provide regulatory relief by repealing existing rules identified by the Presidential Task Force failed, largely because courts demanded the same degree of analysis and explanation for withdrawals of rules as for their initial promulgation. ${ }^{59}$

55 See Presidential Task Force on Regulatory Relief, Reagan Administration Regulatory Achievements 2 (Aug 11, 1983) (on file with U Chi L Rev). See Thomas O. McGarity and Sidney A. Shapiro, Workers at Risk: The Failed Promise of the Occupational Safety and Health Administration 62-63 (Praeger 1993). Although quite active at the outset of the Reagan administration, the Task Force gradually faded into oblivion during its later years.

${ }^{56}$ See Regulatory Reform Act, S 1080, 97th Cong, 1st Sess (Apr 29, 1981), in 127 Cong Rec S7938 (Apr 30, 1981); Regulatory Reform Act, Hearings on S 1080 before the Subcommittee on Regulatory Reform of the Senate Committee on the Judiciary, 97th Cong, 1st Sess 31-34 (1981) (summarizing the Regulatory Reform Act). The House declined to act on this Omnibus Regulatory Reform Bill, which the Senate had passed by a unanimous vote. Diane Granat, Probably Doomed for Year: Rules Committee Fails to Act; Regulatory Reform Stalled, 40 Cong Q Wkly Rep 3029, 3029 (1982).

${ }_{57}$ McGarity, 38 Admin L Rev at 409-12 (cited in note 10). See also McGarity, 45 Md L Rev at 256-57 (cited in note 45) (defining "substantive" regulatory reform).

${ }_{58}$ See McGarity, $45 \mathrm{Md} \mathrm{L}$ Rev at 262 (cited in note 45) (Appointees "were aloof, politically unsophisticated, and to a surprising degree unqualified to perform their statutory responsibilities.").

${ }^{59}$ See, for example, Motor Vehicle Mfrs. Ass'n $v$ State Farm Mutual Auto. Ins. Co., 463 US 29, 42 (1983) ("If Congress established a presumption from which judicial review should start, that presumption ... is not against safety regulation, but against changes in 
The pendulum swung ever so slightly further during the "kinder, gentler" administration of President Bush. Bush's administration left all of the Reagan administration's cognitive and structural reforms in place. In the area of procedural reform, the Bush administration supported the first important statutory attempt to implement the much discussed but little used technique of regulatory negotiation. ${ }^{60}$ Under this approach, a regulatory agency, prior to proposing and receiving comment on a regulation, invites "stakeholders" to sit around a table for a number of days in an attempt to achieve consensus on one or more issues that the rule making will have to resolve. ${ }^{61}$ The regulatory negotiation technique achieved some modest successes in reducing the time and effort expended on a few relatively uncontroversial rulemaking initiatives, but it did not play a significant role in the promulgation of any hotly contested rules. ${ }^{62}$ Early in his administration, President Bush created the Council on Competitiveness to steer the agencies toward substantive regulatory reforms, ${ }^{63}$ but the strong willed and experienced individuals who headed the important regulatory agencies generally held their own in interagency disputes until late in the administration, when the right wing of the Republican Party pushed the Council on Competitiveness to become much more intrusive. ${ }^{64}$

The Bush administration achieved a degree of means-oriented substantive regulatory reform in the massive 1990 amend-

current policy that are not justified by the rulemaking record.").

60 See Negotiated Rulemaking Act of 1990, Pub L No 101-648, 104 Stat 4969, codified at 5 USC §§ 561-70 (Supp 1994).

${ }_{61}$ See Philip J. Harter, Negotiating Regulations: A Cure for Malaise, 71 Georgetown L J 1, 52-97 (1982) (offering a detailed proposal for negotiated rulemaking); 5 USC §§ 56170.

62 See David M. Pritzker, Working Together for Better Regulations, 5 Nat Resources \& Envir 29, 31, 51-53 (Fall 1990) ("[N]egotiated rulemaking [ ] can be valuable to regulatory agencies, regulated entities, and other affected interests."); Susan Rose-Ackerman, Consensus Versus Incentives: A Skeptical Look at Regulatory Negotiation, 43 Duke L J 1206, 1211-12 (1994) ("[C]laims of widespread benefits [from regulatory negotiation] are mostly speculative.").

क The Council on Competitiveness was chaired by Vice President Dan Quayle, and it employed as its executive director a young activist named David McIntosh. McIntosh was elected to Congress in 1994 and has become one of the most avid regulatory reformers in the House of Representatives. See McGarity and Shapiro, Workers at Risk at ch 11 (cited in note 55); Memorandum to Secretary Martin, Department of Labor from the Vice President re: Regulatory Review Process (Mar 15, 1991) (on file with U Chi L Rev) (noting involvement of Council on Competitiveness in regulatory review process and implementation of Exec Order No 12291). 1992).

of See Michael Weisskopf, “Outsider" EPA Chief Being Tested, Wash Post A1 (June 8, 
ments to the Clean Air Act. ${ }^{65}$ The amendments established a multistate trading program for sulfur dioxide emissions from power plants ${ }^{66}$ and encouraged states to consider "economic incentives such as fees, marketable permits, and auctions of emissions rights" in writing their implementation plans. ${ }^{67}$ The administration did not, however, seek substantial substantive changes in the Clean Air Act or any other important regulatory statute.

With the Clinton administration, the pendulum received a slight push back towards active governmental regulation. Nevertheless, President Clinton did support and sign the Unfunded Mandates Reform Act of 1995, which requires agencies to prepare statements detailing the costs and benefits of major regulations and erects procedural barriers to the enactment of legislation that would impose unfunded mandates on states. ${ }^{68}$ President Clinton also promulgated a new executive order that extends the regulatory analysis requirement for major rules. However, this order demands for the first time explicit consideration of a regulation's equity and distributional impacts. In addition, the Clinton order weakened the requirement that an agency select the substantive alternative that maximizes net benefits. ${ }^{69} \mathrm{~A}$ subsequently issued executive order requires every federal agency to "make achieving environmental justice part of its mission by identifying and addressing, as appropriate, disproportionately high and adverse human health or environmental effects of its programs, policies, and activities on minority populations and low-income populations."

The Clinton administration has implemented few structural reforms. Although it immediately disbanded the controversial Council on Competitiveness, ${ }^{71}$ it retained the interagency review

6s Pub L No 101-549, 104 Stat 2399 (1990), codified at 42 USC $\$ \S 7401-7671 q$ (1994).

${ }_{66} 42$ USC $\S 7651(a)$-(o) (1994). See also John E. Bonine and Thomas O, McGarity, The Law of Environmental Protection: Cases-Legislation-Policies 586-87 (West 2d ed 1992) (describing regulatory program for acid deposition created by 1990 amendments).

6742 USC $\$ 7410(a)(2)(A)(1994)$.

68 Pub L No 104-4, 109 Stat 48, to be codified at 2 USC $\S \S 1501-71$.

69 Exec Order No 12866 § 1, 3 CFR 638, 638-39 (1993). See Ellen Siegler, Executive Order 12866: An Analysis of the New Executive Order on Regulatory Planning and Review, 24 Envir L Rptr 10070 (Feb 1994) (detailed review of order).

70 Exec Order No 12898 § 1-101, 3 CFR 859, 859 (1994). The executive order requires all agencies to develop "environmental justice strategies" and provide reports on the implementation of those strategies. Id $\S \S 1-103,1-104,3$ CFR at 860-61.

${ }^{21}$ Clinton Administration Orders Retraction of Dozens of Last-Minute Bush Regulations, 23 Envir Rptr (BNA) 2571, 2572 (1993) (reporting Vice President Al Gore's January 22, 1993, announcement of the elimination of the Council on Competitiveness). 
process and continued to let OMB play the lead role. ${ }^{72}$ OMB must also coordinate agency regulatory plans and publish an annual comprehensive regulatory plan. ${ }^{73}$ As in the past two administrations, a prominent role is envisioned for the Vice President in resolving interagency disputes. ${ }^{74}$ The practice of interagency review, however, is more open and accountable than it was in previous administrations. ${ }^{75}$

From a substantive perspective, the Clinton administration has been more vigorous than the previous two administrations in asserting the protective role of government, ${ }^{76}$ but it has been singularly unsuccessful in advancing that agenda in Congress. The administration has initiated several cooperative efforts in which agencies have encouraged regulated industries voluntarily to take action aimed at reaching broad regulatory goals. ${ }^{77}$ At the same time it has initiated a comprehensive "Eliminating Regulatory Overkill" effort designed to examine all existing rules, and to identify obsolete and ineffective rules and withdraw those rules as quickly as possible. ${ }^{78}$

If the pendulum had begun to swing slightly back toward an active role for government in protecting its citizens, the 1994 elections radically changed the political terrain. The electorate

72 Exec Order No 12866 § 2(b), 3 CFR at 640 (cited in note 69).

${ }^{73}$ Id $\S 4(\mathrm{c}), 3 \mathrm{CFR}$ at $642-43$. In the Reagan and Bush administrations, plans were published twice per year.

${ }^{74}$ Id $\$ 2$ (c), 3 CFR at 640-41.

75 See, for example, Meetings on Pending EPA Regulations Detailed by OIRA under Executive Order, 24 Envir Rptr (BNA) 1478, 1478 (1993) (detailing OIRA disclosure of information on several meetings about pending regulatory matters between the OIRA administrator and outside interest groups).

${ }^{76}$ According to OIRA Administrator Sally Katzen, the Clinton administration believes that "the government has the responsibility to govern, including the responsibility to protect the public, through Federal regulation when the American people-through our constitutional representative process-decides that it should." Regulatory Transition Act of 1995, Hearings before the Subcommittee on National Economic Growth, Natural Resources, and Regulatory Affairs of the House Committee on Government Reform and Oversight, 104th Cong, 1st Sess 34 (Jan 19, 1995) (statement of Sally Katzen, Administrator of OIRA).

7 See, for example, DOE Plans to Seek Alliance with Industry to Help Firms Meet Environmental Standards, 23 Envir Rptr (BNA) 2872, 2872-73 (1993) (reporting on voluntary programs to meet Department of Energy and EPA environmental standards). According to EPA Administrator Carol Browner, these programs are intended to "deadversarialize" the regulatory process. Browner Says Cooperation with Industry Enhances Environmental Policy Development, 24 Envir Rptr (BNA) 322, 322 (1993).

${ }^{78}$ Al Gore, From Red Tape to Results: Creating a Government that Works Better \& Costs Less 32-34 (US GPO 1993) (Initial Report of the National Performance Review). See also Al Gore, Common Sense Government: Works Better and Costs Less 141 (US GPO 1995) (Third Report of the National Performance Review). 
retired several powerful proponents of the regulatory state, and sent to Washington a group of senators and representatives who signed or supported the "Contract with America" and promised to codify cognitive and structural reforms and to initiate radical substantive change in existing regulatory statutes. ${ }^{79}$ Asserting that "[c]urrent federal policies threaten the competitiveness of American business, stifle entrepreneurial activity, and suppress economic growth and job creation, ${ }^{n 80}$ the signatories of the Contract with America promised to enact legislation within the first one hundred days of Congress. ${ }^{81}$

The signatories were true to their word. During the first one hundred days of the 104th Congress, the House passed the Job Creation and Wage Enhancement Act, ${ }^{82}$ which provides for, among other things, neutral cost recovery and cost-benefit analysis, ${ }^{83}$ the Unfunded Mandates Act intended to create jobs, ${ }^{84}$ and, for good measure, a moratorium on new regulations to last

79 Ed Gillespie and Bob Schellhas, eds, Contract with America: The Bold Plan by Rep. Newt Gingrich, Rep. Dick Armey, and the House Republicans to Change the Nation 131-35 (Times 1994).

80 Id at 128 .

s1 Id at $15,18$.

82141 Cong Rec H2639 (Mar 3, 1995). The Job Creation and Wage Enhancement Act was originally introduced in the House of Representatives as HR 9, Titles III, IV, V, VI, VII, VIII, and $X$ of which dealt with regulatory reform. HR 9, 104th Cong, 1st Sess $\S \S$ 3001-5601, 6001-04, 7001-8209, 10001-03 (Jan 4, 1995), in 141 Cong Rec H2607-29 (Mar 3, 1995). To facilitate separate committee consideration, it was broken into several different bills: HR 830 (paperwork reduction); HR 925 (property rights); HR 926 (OMB review, regulatory flexibility, regulatory analysis, regulatee rights); and HR 1022 (risk assessment and cost-benefit analysis). After voting favorably on each of the separate bills, the House then voted to recombine them into HR 9, which was to be called the Job Creation and Wage Enhancement Act.

Although its supporters claimed that the House had passed the Job Creation and Wage Enhancement Act in its entirety within the first one hundred days of the 104th Congress, some important provisions were, in fact, abandoned and never became part of the final version of HR 9. For example, the ambitious proposals for a regulatory budget and a mandates budget in Titles $I V$ and $X$ of the original HR 9 did not survive. Other provisions were deprived of all substantive content in committee. For example, an exceedingly foolish provision of the original bill would have entitled every target of a federal investigation to prior notice of the investigation and to have an attorney or accountant present at any interrogation. HR $9 \S 8101$, in 141 Cong Rec at H2618-19. As the Deputy Attorney General testified to the House Judiciary Committee, this provision would have "vastly expand[ed] the rights of criminal defendants" and hamstrung the Federal Bureau of Investigation and the Drug Enforcement Administration in their investigation of criminal conduct. Job Creation and Wage Enhancement Act of 1995, Hearings on HR 9 before the Subcommittee on Commercial and Administrative Law of the House Committee on the Judiciary, 104th Cong, 1st Sess 137 (Feb 3, 1995) (statement of Jamie Gorelick, Deputy Attorney General).

HR $9 \S \S 2001,3001-3301$, in 141 Cong Rec at H2610-13 (cited in note 82).

st HR 5, 104th Cong, 1st Sess (Jan 4, 1995), in 141 Cong Rec H2209-10 (Jan 5, 1995). 
until Congress had a chance to revise or repeal the statutes under which the regulations were promulgated. ${ }^{85}$ The House next began serious consideration of comprehensive amendments to many of the statutes that have historically provided the underpinnings for federal health, environmental, and consumer fraud protections. When the legislative process began to bog down at the end of the summer of 1995, radical deregulatory measures began to appear as riders to House appropriations legislation. ${ }^{86}$

In the Senate, the pace has been much slower. The Senate passed and the President signed the relatively uncontroversial unfunded mandates legislation ${ }^{87}$ and a reauthorization of the Paperwork Reduction Act that extended OMB's authorization for an additional five years and provided a goal of a 5 percent reduction in federally required paperwork per year. ${ }^{88}$ Although the unfunded mandates legislation has the potential to bog down agencies in cost-benefit analysis, it should be no more burdensome than the existing analytical requirements of the Clinton executive order. The most important impact of the unfunded mandates legislation may be to offer opponents of future protective legislation additional opportunities to impede its progress through Congress. ${ }^{89}$ Likewise, while the Paperwork Reduction Act reauthorization will make it more difficult for federal agencies to gather information, it should have very little impact on the way agencies promulgate protective rules. The Senate also passed a "report and wait" version of the legislative veto that would give Congress the opportunity to enact legislation overturning administrative rules before they were implemented. ${ }^{90}$

85 Regulatory Transition Act of 1995, HR 450, 104th Cong, 1st Sess (Feb 24, 1995), in 141 Cong Rec H2209-10 (Feb 24, 1995).

${ }_{86}$ See, for example, House Appropriations Panel Backs EPA Cuts; Efforts Fail To Strike Environmental Riders, 26 Envir Rptr (BNA) 593, 593-94 (1995).

87 Pub L No 104-4, 109 Stat 48 (1995), to be codified at 2 USC $\S \S 1501$ et seq.

${ }_{8 s}$ Pub L No 104-13, 109 Stat 163 (1995). The Paperwork Reduction Act reauthorization will have a potentially serious impact on the OSHA, because it explicitly overrules the Supreme Court's holding in Dole $v$ United Steelworkers of America, 494 US 26,43 (1990), that OSHA was not required to obtain OMB approval of informational requirements that it placed on regulatees.

89 The unfunded mandates legislation establishes a procedure whereby any legislation that would impose requirements on state, local, or tribal governments of greater than fifty million dollars in a single fiscal year (with some exceptions) will be subject to a point of order in either house of Congress unless the bill also provides for federal funding to meet the requirements. Unfunded Mandates Reform Act § 425, 109 Stat at 56-58.

${ }_{90}$ S 219, 104th Cong, 1st Sess (Mar 16, 1995). See Timothy Noah, Senate to Consider Less Sweeping Bill On Regulatory Moratorium Than House, Wall St J A2 (Mar 22, 1995). Most versions of the legislative veto were declared unconstitutional in INS $v$ Chadha, 462 US 919, 944-59 (1983). The "report and wait" version of the legislative veto eliminates 
As of this writing, however, the Senate has not passed omnibus regulatory reform legislation, nor has the full Senate agreed to the moratorium that the House passed in the spring of 1995. Although several Senate committees are studying comprehensive amendments to the substantive regulatory statutes, only one of any importance (telecommunications regulatory reform) has come to the Senate floor. Like the House, the Senate has passed some "rifle shot" riders to appropriations bills aimed at providing particular instances of regulatory relief, and a few have become law. ${ }^{91}$

Although the 104th Congress has enacted little important regulatory reform legislation thus far, the second session may see the enactment of omnibus legislation and specific substantive amendments to enabling statutes. In any event, the bills that have passed the House and nearly passed the Senate will serve as models for future regulatory reform legislation. Thus, while it is too soon to know which way the pendulum of reform will swing in the near term, we can be sure that the regulatory state will not go unchallenged in the future.

\section{THE EXPANDED DEBATE OVER REgULATION}

The radical assault on regulation in the 104th Congress has had a powerful impact on political discourse. More frequently than at any time since the first years of the New Deal, the debate over the proper role of government in society has been a topic of everyday conversation. In many ways, the scope of the debate is broader and the divisions in attitudes deeper than at any time since the early 1890 s when agrarian populists, radical worker groups, remnants of the Liberal Republicans and Mugwumps, "single tax" followers of Henry George, utopian disciples of Edward Bellamy and William Demerest Lloyd, academic economists like Richard Ely, laissez-faire apostles of Herbert Spencer and William Graham Sumner, and spokesmen for the powerful and entrenched banks, corporations, and trusts all debated the future of the American economy. In this sense, regulation is clearly at a crossroads. For those who study regulation, these are exciting times; for those who feel unduly constrained by regula-

constitutional objections because it requires bicameral legislation signed by the President to overturn a given administrative rule.

91 See, for example, National Highway System Designation Act of 1995 § 348, Pub L No $104-59,109$ Stat 568 , to be codified at 23 USC $\S 348$ (placing a moratorium on certain emissions testing requirements). 
tion, these are heady times; and for those who have depended upon the federal government to protect them from the unconstrained exercise of private economic power, these are dangerous times.

In the remainder of this Essay, I will attempt to characterize five important positions in this multifaceted debate over the future of the regulatory state and to outline briefly some of the most significant points of friction. For purposes of illustration, I will focus primarily on the debate over the nature of the employment relationship and the future of health and environmental protection. In the process, I hope to illuminate some of the choices that are available and to identify some of the pitfalls to be avoided.

\section{A. Radical Anti-Interventionists}

The radical anti-interventionists agree wholeheartedly with President Reagan's sentiment that government is not the solution-it is the problem. ${ }^{92}$ They therefore flatly reject nearly all of the regulatory legislation that Congress enacted during the Progressive, New Deal, and civil rights-public interest eras. ${ }^{93}$ They unabashedly seek a return to the "golden age" of the last quarter of the nineteenth century when business-oriented laissez-faire reigned supreme in all three branches of the federal government. ${ }^{94}$ The radical anti-interventionists are "conservative" not in their desire to preserve existing institutions, but in their hope of restoring the values and hierarchies that prevailed from the end of the Civil War to the first one hundred days of the New Deal. While seizing the mantle of "reform," they nevertheless demand that the beneficiaries of the existing regulatory regime justify the institutions and laws that protect them, as if it were the beneficiaries who were seeking radical change. They rely mostly on highly abstract and neutral-sounding theoretical argu-

92 Inaugural Address, 1981 Pub Papers Pres 1, 1.

93 I would place within the "radical anti-interventionist" category such writers as William F. Buckley, Richard Epstein, Milton Friedman, George Gilder, Friedrich von Hayek, Russell Kirk, and Charles Murray. The radical anti-interventionist position is typically advanced in such conservative think tanks as the Cato Institute and the Heritage Foundation. The description below relies primarily upon the writings of these authors.

4 Milton Friedman and Rose Friedman, Free to Choose: A Personal Statement 3 (Harcourt Brace Jovanovich 1980). See also Julius G. Getman and Thomas C. Kohler, The Common Law, Labor Law, and Reality: A Response to Professor Epstein, 92 Yale L J 1415, 1415 (1983) (criticizing Professor Richard Epstein for taking "the 'common law' (in its late nineteenth-century form) as the appropriate 'benchmark' against which to judge 'modern statutory schemes" $)$. 
ments for why laissez-faire represents the best state of the world in nearly all contexts, and they insist that the beneficiaries come up with similarly abstract theories to support government intervention. ${ }^{95}$

\section{Dualistic view of government and markets.}

Most of the radical anti-interventionists view the political economy in a rather clear-cut, dualistic fashion in which the only alternative to a freewheeling capitalist system is a tyrannical, morally corrupt, and economically impoverished collectivist system. Perhaps the most consistent theme throughout all of the modern laissez-faire literature is the axiom that a government that would preserve political freedom must also protect economic freedom. ${ }^{96}$ As proof, they offer the horror stories of Russia, Eastern Europe, and China. ${ }^{97}$ Centralized decision making is necessarily bad decision making, because bureaucrats can never stay far enough ahead of technological and economic change to prescribe workable rules and regulations for all potentially abusive or harmful practices in the private sector. ${ }^{98}$ In Hayek's frightening metaphor, once we turn toward centralized governmental intervention to solve society's problems, we are headed down the "road to serfdom."

${ }_{95}$ For example, Professor Epstein, in attempting to rebut the impressive demonstration by Professors Getman and Kohler that Epstein's view of the history of the at-will employment doctrine was badly in error, responded that "it takes a theory to beat a theory." Richard A. Epstein, Common Law, Labor Law, and Reality: A Rejoinder to Professors Getman and Kohler, 92 Yale L J 1435, 1435 (1983). See also Michael H. Gottesman, Wither Goest Labor Law: Law and Economics in the Workplace, 100 Yale L J 2767, 2775 (1991) (agreeing with Professor Epstein). This assertion is preposterous on its face. To beat a theory about how the world works, it takes only reality. If the facts are inconsistent with the theory, the theory loses its explanatory power (and the normative conclusions that flow from the theory are thereby rendered suspect), whether or not a better theory is available to replace it.

${ }_{96}$ This axiom is repeated in the modern laissez-faire literature too often to be captured in a single footnote of reasonable length. Two prominent examples are Milton Friedman, Capitalism and Freedom 4 (Chicago 1962), and Friedrich A. Hayek, The Road to Serfdom 88-100 (Chicago 1944).

${ }_{97}$ See, for example, Friedman, Capitalism and Freedom at 7-10 (cited in note 96); Friedman and Friedman, Free to Choose at 3, 54-57, 146-48 (cited in note 94).

${ }_{98}$ See George Gilder, Wealth and Poverty 26-27 (Basic Books 1981).

99 Hayek, The Road to Serfdom (cited in note 96). See also Gilder, Wealth and Poverty at 27 (cited in note 98 ). 


\section{Affinity for late nineteenth-century laissez-faire} capitalism.

The radical anti-interventionists not only strongly oppose new federal regulatory programs, they also want to destroy most of the existing programs. The securities laws, ${ }^{100}$ the wage and hour laws, ${ }^{101}$ the employment discrimination laws, ${ }^{102}$ and even the venerable National Labor Relations Act ("NLRA") ${ }^{103}$ should all be repealed. Most federal regulation is, in their view, inconsistent with the three pillars of a laissez-faire political economy-private property, freedom of contract, and allocative efficiency.

The radical anti-interventionists tend to view private property in very absolute and expansionist terms. In what may fairly be characterized as an appeal to natural law, they view property rights as exogenous or prepolitical, existing apart from the political process and therefore not subject to redefinition by popular government. ${ }^{104}$ If modern legislatures may not appropriately define the parameters of property, where do we look for those definitions? For the radical anti-interventionists, the best answer to that question is the late nineteenth-century common law courts. ${ }^{105}$

${ }^{100}$ See George J. Stigler, Public Regulation of the Securities Market, reprinted in George J. Stigler, The Citizen and the State: Essays on Regulation 71, 81-82, 99 (Chicago 1975).

101 See Richard A. Epstein, Standing Firm, on Forbidden Grounds, 31 San Diego L Rev 1, 54 (1994); Friedman and Friedman, Free to Choose at 237 (cited in note 94).

${ }_{102}$ See Richard A. Epstein, Forbidden Grounds: The Case Against Employment Discrimination Laws 412 (Harvard 1992) ("It is now both possible and necessary to begin with a blank slate."). See also id at 9 ("[T]he entire apparatus of the antidiscrimination laws in Title VII should be repealed .....”).

${ }_{103}$ See Richard A. Epstein, A Common Law for Labor Relations: A Critique of the New Deal Labor Legislation, 92 Yale L J 1357, 1357 (1983).

104 See, for example, Richard A. Epstein, An Outline of Takings, 41 U Miami L Rev 3, 5 (1986) ("Political organization is thus best understood as arising out of a network of forced exchanges in which individuals are taxed by the state and receive in exchange the protection of the remainder of their holdings not taken by taxation.").

${ }_{105}$ See id at 7 ("If there is no central state already in place, the mode of acquisition will have to be, as the older common lawyers had it, by 'natural' acquisition.").

At the same time that they would vest the owners of private property with expanded powers to resist government intrusion, the radical anti-interventionists would greatly narrow the concept of property to include those things (for example, land, chattels, incorporeal hereditaments) that were recognized at nineteenth-century common law, and few others. In particular, they reject the notion that welfare payments made under governmental entitlement programs represent the sort of property that merits vigorous protection. See Epstein, 92 Yale L J at 1361 (cited in note 103) ('Welfare payments are never a matter of a legal entitlement of the recipients, but only an expression of collective benevolence by the transferors."). 
The attitude of the radical anti-interventionists toward freedom of contract is most apparent in the context of employment contracts:

The appropriate strategy in all cases . . is to open up markets to new entry as quickly as possible, to eliminate as many of the impediments on the employment relationship-unemployment taxation, the minimum wage, antidiscrimination law, most health and safety regulation-and to allow employers and employees to work their separate peace on mutually agreeable terms. ${ }^{106}$

The radical anti-interventionists are thus enthusiastic supporters of the late nineteenth-century view that employers should have the right to fire employees for good reasons, for bad reasons, or for no reason at all. ${ }^{107}$ The radical anti-interventionists reject the suggestion that unequal bargaining power justifies protective labor legislation; employers must compete for good laborers just as employees compete for good jobs. ${ }^{108}$ Indeed, the at-will doctrine is actually beneficial to employees, because "the employee may not realize that it is best to quit a job to which he is not suited and to seek a more suitable job. ${ }^{\text {109 }}$

Although the radical anti-interventionists are not strict utilitarians, they can usually find efficiency rationales for arguing against government regulation. They cite, for example, efficiency arguments for retaining the employment-at-will doctrine. Employees will work harder and produce more if they know they can be fired for shirking their responsibilities. Employers will be able to arrange production processes more efficiently if they have the power to fire laggards and troublemakers. ${ }^{110}$

206 Epstein, 31 San Diego L Rev at 2 (cited in note 101).

107 See Richard A. Epstein, In Defense of the Contract at Will, 51 U Chi L Rev 947, 947-48 (1984), citing Payne v Western \& Atlantic Railroad, 81 Tenn 507, 518-19 (1884), overruled on other grounds, Hutton $v$ Watters, 132 Tenn 527, 179 SW 134, 138 (1915).

108 Epstein, 92 Yale L J at 1360 (cited in note 103). See also Gottesman, 100 Yale L J at 2771-72 (cited in note 95) (describing radical anti-interventionist position).

${ }^{109}$ Richard W. Power, Defense of Employment at Will, 27 SLU L J 892 (1983).

110 See Jack M. Beermann and Joseph William Singer, Baseline Questions in Legal Reasoning: The Example of Property in Jobs, 23 Ga L Rev 911, 922 (1989); Epstein, $51 \mathrm{U}$ Chi L Rev at 965-66 (cited in note 107); Power, 27 SLU L J at 895 (cited in note 109); Stewart J. Schwab, Life-Cycle Justice: Accommodating Just Cause and Employment at Will, 92 Mich L Rev 8, 21-24 (1993). 


\section{Opposition to the modern regulatory state.}

The radical anti-interventionists are fundamentally opposed to most of the landmark legislation of the modern regulatory state. They are not fond of collective bargaining and trade unions, and they would repeal or severely limit the NLRA because it grants too much power to unions. ${ }^{111}$ By forcing the cost of the labor of organized workers to rise, labor unions both increase the prices that consumers pay for goods and services and reduce the demand for unorganized workers. ${ }^{112}$ The radical anti-interventionists also urge the repeal of the Davis-Bacon Act, which requires federal contractors to pay the prevailing wage, because that rate is normally the union rate and the union rate is usually inefficient. ${ }^{113}$

The employment discrimination statutes are also on the radical anti-interventionists' list of laws destined for the dustbin. Because they doubt that any employer who irrationally discriminates against qualified workers could long survive in a competitive marketplace, they are dubious about the potential for antidiscrimination laws to bring about much social good. ${ }^{114}$ The appropriate way to deal with bigoted employers is to attempt to persuade them of the error of their ways, not to subject them to regulations and lawsuits. ${ }^{115}$ Some radical anti-interventionists are convinced that in many contexts, discrimination based on race, sex, national origin, and religion is not irrational. ${ }^{116}$ Discrimination against women and minorities can minimize the "governance costs" of controlling unruly workers who have a "taste" for discrimination. ${ }^{117}$ In addition, the high cost of acquir-

11 See Epstein, 92 Yale L J at 1406 (cited in note 103); Friedman and Friedman, Free to Choose at 229-42 (cited in note 94).

112 Friedman and Friedman, Free to Choose at 233-35 (cited in note 94). See Samuel Issacharoff, Reconstructing Employment, 104 Harv L Rev 607, 618-19 (1990) (describing the radical anti-interventionist position).

${ }^{113}$ Friedman and Friedman, Free to Choose at 236-37 (cited in note 94).

114 See Gary S. Becker, The Economics of Discrimination 39-55 (Chicago 2d ed 1971) (describing the price employers must pay to satisfy their "taste for discrimination"); Epstein, 31 San Diego L Rev at 1 (cited in note 101) ("[T]he best set of overall social outcomes would come from a legal order that tolerated any form of private discrimination or favoritism, whether practiced by the most vicious and ardent white supremacist or the most dedicated proponent of diversity or affirmative action."); Friedman, Capitalism and Freedom at 109-10 (cited in note 96).

115 Friedman, Capitalism and Freedom at 110-11 (cited in note 96).

116 See, for example, Epstein, Forbidden Grounds at 72-73, 266 (cited in note 102).

117 Id at 60-69. Professor Epstein explains: "To the extent, therefore, that individual tastes are grouped by race, by sex, by age, by national origin-and to some extent they are-then there is a necessary conflict between the commands of any antidiscrimination 
ing accurate predictive information about future job performance may lead employers to use broad "rules of thumb" in hiring that are discriminatory in practice but enhance overall efficiency. For example, radical anti-interventionists believe that since genderbased discrimination is normally based on legitimate biological distinctions, it would be inefficient for society to waste its scarce resources in forcing employers to treat women equally. ${ }^{118}$ In any event, they are convinced that any system of government regulation and enforcement of employment discrimination laws will inevitably do more harm than good. ${ }^{119}$ Tolerating a few bigoted companies will not significantly reduce overall job opportunities for women and minorities who can always seek employment with more enlightened employers. ${ }^{120}$

Occupational safety and health laws, in the minds of the radical anti-interventionists, unduly restrict employer and employee freedom of contract and waste scarce resources. Employers invest too much in training workers to allow them to be killed and maimed for no reason. Workers will bid up wages for risky work, thereby encouraging further employer efforts to install safety technologies. ${ }^{121}$ And keeping workplaces reasonably safe will reduce the number of tort and workers' compensation claims. Hence, the best way to address workplace risks is to allow individual employees and employers to bargain over them, just as they bargain over wages, and leave the rest to state workers' compensation laws. ${ }^{122}$ As Chicago School founder Frank Knight observed, a primary distinction between laborers and company

law and the smooth operation of the firm." Id at 66-67.

118 See id at 271-72; Gilder, Wealth and Poverty at 128-39 (cited in note 98) (discussing race- and sex-based "myths of discrimination"); Kathryn Abrams, Social Construction, Roving Biologism, and Reasonable Women: A Response to Professor Epstein, 41 DePaul L Rev 1021, 1021-22 (1992) (impliedly attributing such views to Richard Epstein).

11 Epstein, 31 San Diego L Rev at 1 (cited in note 101).

120 Epstein, Forbidden Grounds at 72-76 (cited in note 102). Indeed, Professor Epstein suggests that allowing bigoted employers to discriminate may be beneficial to the erstwhile victims of that discrimination. "If all the bigots and troublemakers are isolated in a small number of firms, other workers have a more attractive array of firms to choose from than they would if bigoted workers were distributed randomly across all firms." Id at 74 .

${ }^{121}$ See McGarity and Shapiro, Workers at Risk at 18-20 (cited in note 55) (discussing economic theory that workers will demand a "wage premium" to compensate them for risk); W. Kip Viscusi, Risk by Choice: Regulating Health and Safety in the Workplace 3845 (Harvard 1983).

${ }_{122}$ See Robert Stewart Smith, The Occupational Safety and Health Act, Its Goals and Achievements (AEI 1976); Richard Zeckhauser and Albert Nichols, The Occupational Safety and Health Administration-An Overview, in Committee on Governmental Affairs, United States Senate, 6 Study on Federal Regulation (Appendix), 95th Cong, 2d Sess 161, 171-72 (1978). 
owners is that laborers have freely elected to risk their health and safety whereas owners have chosen instead to risk their capital. ${ }^{123}$

The radical anti-interventionists recognize that environmental pollution often represents a failure of the market in that the polluter is allowed to externalize risks to the citizens of the community without paying for the privilege. ${ }^{124}$ Nevertheless, they would prefer to handle such externalities with the common law of torts, by forcing polluters to compensate their victims after the fact, or with flexible incentives such as effluent charges and marketable permits that are aimed at achieving pollution reduction goals that pass a strict cost-benefit test. ${ }^{125}$ Other kinds of safety regulation (for example, food safety and consumer product safety) are less justifiable to the radical anti-interventionists. Since consumers can choose from among many competing products, manufacturers have a natural incentive not to sell products that will poison or injure their customers, and the threat of common law liability provides an additional incentive to design and market safe products. Regulation does more harm than good by retarding innovation on the part of manufacturers. ${ }^{126}$ Therefore, agencies like the FDA should be eliminated. ${ }^{127}$

The radical anti-interventionist commitment to private property clashes directly with the claims of environmental preservationists. For example, the radical anti-interventionists are not at all sympathetic to claims that the goal of preserving wetlands and habitats of endangered species warrant governmental restrictions on the use of private property, and they would insist that the government compensate property owners for any substantial diminution in value attributable to such restrictions. ${ }^{128}$ 1957).

${ }^{123}$ See Frank H. Knight, Risk, Uncertainty and Profit 300-01 (Kelley \& Millman

${ }^{124}$ See Friedman, Capitalism and Freedom at 30 (cited in note 96); Friedman and Friedman, Free to Choose at 31 (cited in note 94).

125 See Friedman and Friedman, Free to Choose at 31-32, 215-17 (cited in note 94).

126 Gilder, Wealth and Poverty at 239-41 (cited in note 98).

127 Friedman and Friedman, Free to Choose at 208-09 (cited in note 94).

128 See Epstein, 41 U Miami L Rev at 12-13 (cited in note 104); Nancie G. Marzulla, State Private Property Rights Initiatives As a Response to "Environmental Takings", 46 SC L Rev 613, 623-28 (1995). 
4. Tolerance for large disparities in wealth.

Large disparities in the distribution of income and wealth among the citizenry are of little concern to the radical anti-interventionists. Like Adam Smith, they believe that as individuals pursue greater wealth in the marketplace, the wealth of the entire society grows. Conversely, government-induced transfers of wealth, whether effected directly through taxation and distribution of government benefits or indirectly through regulation, tend "to reduce the overall level of social welfare."129 The best gauge of the health of a country's political economy is how well it treats the rich. ${ }^{130}$ Bettering the lot of the disadvantaged is a job for churches and private charities, not the state.

\section{B. Free Marketeers}

The regulatory reformers in the second category recognize that government can play a role in improving society, but they are highly suspicious of most governmental regulation as implemented in the real world. ${ }^{131}$ Like the radical anti-interventionists, they prefer that the government not intervene in the market except when it is playing its minimal role in enforcing contracts, protecting private property, and specifying the foundational rules for the marketplace. They recognize, however, that markets do not always function perfectly and that government intervention might be required to address market imperfections. Nevertheless, free marketeers strongly believe that the market is the benchmark against which all "corrective" intervention should be measured, and they would erect a strong presumption against government regulation. ${ }^{132}$ In addition, they caution that regula-

129 Epstein, 41 U Miami L Rev at 18-19 (cited in note 104). See also Friedman, Capitalism and Freedom at 172-76 (cited in note 96) ("Distribution of income is [an] area in which government has been doing more harm by one set of measures than it has been able to undo by others.").

130 Gilder, Wealth and Poverty at 50 (cited in note 98) ("How the rich are regarded and how they see themselves-whether they are merely rich or also bearers of wealth-is a crucial measure of the health of a capitalist economy.").

132 This category may well encompass the largest number of current students of regulation. It includes most neoclassical economists, most students of regulation in the law and economics movement, and dozens of analysts in conservative think tanks and government agencies. Prominent free marketeers include Stephen Breyer, Robert Cooter, Robert Crandall, Christopher DeMuth, George Eads, Daniel Fischel, Robert Hahn, Lester Lave, John Mendeloff, Daniel Polsby, Richard Posner, Charles Schultze, Richard Stewart, W. Kip Viscusi, and Richard Zeckhauser.

${ }_{132}$ See, for example, Charles L. Schultze, The Public Use of Private Interest 16-22 (Brookings 1977); Mayer G. Freed and Daniel D. Polsby, Just Cause for Termination Rules 
tion has failings of its own and warn against "mismatches" between market failures and the regulatory tools used to address them. ${ }^{133}$

\section{Faith in the free market.}

The free marketeers share the radical anti-interventionists' faith in the free market as a fair and efficient vehicle for allocating scarce resources, but they lack the radical anti-interventionist moral commitment to property rights and freedom of contract. ${ }^{134}$ Economic efficiency is their guiding light. Free markets are preferable to regulated markets because free markets are generally more efficient. But free markets are subject to failure for a number of reasons: consumers or workers may have insuffcient information to make rational choices; companies may impose uncompensated costs or risks (externalities or spillovers) on other private parties; or transaction costs, free riders, or holdouts may render private bargains infeasible. When it becomes clear that real-world markets are not functioning efficiently, then government intervention is warranted (and property rights and freedom of contract may have to be sacrificed) to the extent necessary to correct the market failures. ${ }^{135}$ Since government regulation can also lead to inefficient results, government should adopt the least restrictive form of regulation capable of fixing the market's failure to achieve an efficient outcome. ${ }^{136}$ In short, the free marketeers, unlike the radical anti-interventionists, have made their peace with the regulatory state, but insist on the broken-market paradigm as the primary justification for government regulation.

\section{Cost-benefit test for governmental intervention.}

The free marketeers not only begin with a presumption against regulation, they also have in mind a particular test for determining when that presumption may be overcome. Having

and Economic Efficiency, 38 Emory L J 1097, 1098-99 (1989).

133 See Breyer, 92 Harv L Rev at 586-604 (cited in note 7); Robert Cooter, Market Affirmative Action, 31 San Diego L Rev 133, 134 (1994).

${ }^{134}$ See Breyer, 92 Harv L Rev at 552 (cited in note 7) ("[T]he assumption that an unregulated marketplace is the norm does not rest on the adoption of a particular set of values.").

${ }^{135}$ See Richard B. Stewart, Reconstitutive Law, 46 Md L Rev 86, 88-89 (1986) (urging greater use of decentralizing, reconstitutive strategies to promote efficiency and innovation).

${ }^{136}$ See Breyer, 92 Harv L Rev at 586 (cited in note 7). 
identified an instance of market failure, proponents of regulation must demonstrate that the social benefits of any particular governmental intervention will outweigh the costs. ${ }^{137}$ To the extent possible, this demonstration must be made quantitatively using models that use "best case" rather than "worst case" assumptions and employ economic valuation techniques to express costs and benefits in equivalent units (dollars, for example). ${ }^{138}$

The free marketeer position goes beyond the widely accepted cognitive reform of requiring agencies to prepare cost-benefit analyses to accompany major rules for the purpose of informing the decision maker and the public. The free marketeers would employ cost-benefit balancing as the predominant (some would say only) substantive decision-making criterion. Rather than amending agency enabling statutes outright, the free marketeers would repeal by implication all statutory requirements that are inconsistent with the cost-benefit decision-making criterion.

Although recognizing that government regulation may be needed to address the "externalities," most free marketeers are highly skeptical of provisions found in many public health and environmental statutes calling for agencies to adopt a "pollution reduction" or "technology based" approach to standard setting. ${ }^{139}$ Such statutes typically require the agency to divide industries into categories and subcategories, identify pollution reduction technologies in use in the industry or available for transfer from similar industries, and establish standards requiring a specified degree of pollutant removal. Cost and feasibility considerations are relevant, but the agency must set standards without regard to the benefits that their implementation will yield. The purpose of pollution reduction standards is to ensure that sources do the best they can to protect health and the environment, even if a detailed cost-benefit analysis would suggest

${ }^{237}$ See id at 570 ("Ideally, one might expect regulators to set standards through the use of cost-benefit principles.").

${ }^{138}$ See, for example, Allen V. Kneese and Charles L. Schultze, Pollution, Prices, and Public Policy 71 (Brookings 1975); John M. Mendeloff, The Dilemma of Toxic Substance Regulation: How Overregulation Causes Underregulation at OSHA 232-34 (MIT 1988); Robert M. Solow, The Economist's Approach to Pollution and Its Control, 173 Science 498, 500-02 (1971).

${ }^{139}$ See, for example, Mendeloff, Dilemma of Toxic Substance Regulation at 172-73 (cited in note 138); Larry E. Ruff, Federal Environmental Regulation, in Committee on Governmental Affairs, United States Senate, 6 Study on Federal Regulation: Framework for Regulation (Appendix), 95th Cong, 2nd Sess 251, 252 (1978) (Best policies let technology and economics, rather than preselected environmental goals, determine discharge reductions.). 
that less pollution reduction would be more efficient. ${ }^{140}$ The free marketeers complain that the pollution reduction approach requires "technology for technology's sake." They would therefore repeal such provisions outright or by implication by enacting a cost-benefit supermandate. ${ }^{141}$

The free marketeers are also suspicious of statutes that require agencies to make public health or environmental protection the primary goal and preclude or limit the role that cost considerations can play in setting standards. ${ }^{142}$ Failing to balance costs against benefits will result in needless expenditures to reduce or eliminate the "last ten percent" of the risks posed by environmental contaminants. ${ }^{143}$ The free marketeers realize that statutes that promise a "safe" workplace or environment may have important symbolic advantages, but these advantages are greatly outweighed by the practical difficulty in implementing them over staunch regulatee resistance. ${ }^{144}$ Pointing to cost-benefit studies indicating that some federal regulations have cost tens or even hundreds of millions of dollars per life saved, they argue that there must be some limit to the costs that society imposes in pursuit of health and environmental goals. ${ }^{145}$

Some free marketeers suggest that "too stringent" protections that fail a cost-benefit test may perversely result in real-world

${ }^{140}$ See Thomas O. McGarity, Media-Quality, Technology, and Cost-Benefit Balancing Strategies for Health and Environmental Regulation, 46 L \& Contemp Probs 159, 162-65 (Summer 1983).

${ }^{141}$ See HR 9 \$ 3201, in 141 Cong Rec at H2612 (cited in note 82) (requiring agencies promulgating major rules to certify that benefits outweigh costs); Mendeloff, Dilemma of Toxic Substance Regulation at 232 (cited in note 138) (suggesting cost-benefit analysis would cure OSHA's problems of under- and overregulation).

${ }^{142}$ See Lester B. Lave and Gilbert S. Omenn, Clearing the Air: Reforming the Clean Air Act 14-15 (Brookings 1981). For example, the Clean Air Act requires the EPA to set national primary ambient air quality standards at a level that will protect the public health with an adequate margin of safety, without regard for the cost of attaining the standards. 42 USC \& 7409(b)(1) (1988 \& Supp 1993). See Natural Resources Defense Council, Inc. v EPA, 902 F2d 962, 972-73 (DC Cir 1990) (National ambient air quality standards for particulate matter must not include consideration of cost of consequent unemployment.); Lead Industries Association v EPA, 647 F2d 1130, 1150 (DC Cir 1980) (agency precluded from considering economic factors when developing national ambient air quality standards for lead).

${ }^{143}$ Stephen Breyer, Breaking the Vicious Circle: Toward Effective Risk Regulation 11 (Harvard 1993).

${ }^{144}$ See John P. Dwyer, The Pathology of Symbolic Legislation, 17 Ecol L Q 233, 234 (1990).

145 See Breyer, Breaking the Vicious Circle at 11-19 (cited in note 143); Martin J. Bailey, Reducing Risks to Life: Measurement of the Benefits 26 table 4 (AEI 1980) (tables showing costs of lives saved ranging from $\$ 37,500$ to $\$ 624,976,000$ ). See generally Mendeloff, Dilemma of Toxic Substance Regulation at 21-71 (cited in note 138). 
protections that are in fact less beneficial than cost-effective protections would be. Drawing on the frustrating history of OSHA's attempts to promulgate occupational health standards, for example, Professor Mendeloff suggests that "overregulation causes underregulation." 146 Greater health benefits could be achieved, he maintains, if OSHA would not attempt to protect every exposed individual from all health risks. Rather, the goal should be to protect a larger number of persons exposed to a wider variety of sources of risk to a lesser degree. Regulatees will be more likely to accept less stringent standards that are not expensive to implement, and will be less likely to challenge them in court. Courts in turn will be less likely to set aside standards that impose only reasonable costs on regulatees. ${ }^{147}$

In the area of occupational health and safety regulation, most free marketeers would focus on information, rather than protective technologies. Well informed employees will bargain up wages for jobs that entail large degrees of risk, and employers will take health or safety precautions when it is more efficient to do so. ${ }^{148}$ When it is impossible to inform employees fully about workplace risks, because information is unavailable or too difficult to communicate, the free marketeers accept governmental standard setting, but insist that the standards pass the costbenefit test. ${ }^{149}$

The free marketeers support the employment-at-will doctrine on efficiency grounds. They believe that market forces steer employers away from arbitrary hirings and firings, because hiring a bad employee or firing a good one will place the employer at a competitive disadvantage. ${ }^{150}$ As in other areas, government intrusion into the hiring and firing process is likely to do more harm than good, if for no other reason than because it will entail paperwork and litigation costs. ${ }^{151}$ Since employees will ultimately pay for increased job security with decreased wages, it may not even be in the employees' best interest. ${ }^{152}$ Since bigot-

\footnotetext{
${ }^{146}$ Mendeloff, Dilemma of Toxic Substance Regulation at 8-12, 141-43 (cited in note 138).

147 Id at 219-27.

${ }_{148}$ See Viscusi, Risk by Choice at 156-68 (cited in note 121); Mendeloff, Dilemma of Toxic Substance Regulation at 212-17 (cited in note 138); Zeckhauser and Nichols, Occupational Safety and Health Administration at 172-74 (cited in note 122).

149 See Bailey, Reducing Risks to Life at 23-24 (cited in note 145); Mendeloff, Dilemma of Toxic Substance Regulation at 232 (cited in note 138); Zeckhauser and Nichols, OSHA Overview at 170 (cited in note 148).

150 See Freed and Polsby, 38 Emory L J at 1098-99 (cited in note 132).

151 See id at 1127-30.

152 See id at 1102; Jeffrey L. Harrison, The "New" Terminable-at-Will Employment
} 
ed employers who have an irrational "taste for separation" should in the long run have a less productive workforce, competitive pressures in a free market should drive such employers out of business. ${ }^{153}$ Thus, any persistent irrational discrimination must result from market failures that allow bigots to shift the cost of discrimination to the victims. Such market imperfections might include the great cost of acquiring accurate job-related information and the inability of predictive models to predict future performance of job applicants. ${ }^{154}$ Although skeptical of statutes strictly banning employment discrimination against protected minorities, the free marketeers support limited employment discrimination requirements aimed at eliminating serious market failures.

\section{Market-based solutions to social problems.}

The free marketeers also strongly believe that when government intervention is justified, the government should adopt regulatory tools that most efficiently ensure that the benefits of the intervention outweigh its costs. Instead of "command-and-control" regulation, they would recommend market-based programs, like pollution charges and marketable permits to pollute. ${ }^{155}$ Similar-

Contract: An Interest and Cost Incidence Analysis, 69 Iowa L Rev 327, 336 (1984). The free marketeers are, however, willing to entertain exceptions in instances where the benefits of protecting employees from arbitrary hiring and firing practices clearly outweigh the costs. Freed and Polsby, 38 Emory $L J$ at 1104 (cited in note 132) (making "arguments . . . in favor of paternalism" in cases where it will reduce employers' agency costs or increase employee incentives). For example, they appear willing to tolerate some of the "public interest" exceptions for employees fired for whistleblowing, voting, refusing to engage in illegal conduct, or engaging in lawful union activities. See Estlund, 74 Tex L Rev at 166269 (cited in note 6) (describing the economists' acceptance of some exceptions to the employment-at-will doctrine).

${ }_{153}$ See Becker, Economics of Discrimination at 20-21, 44 (cited in note 114); Cooter, 31 San Diego L Rev at 139 (cited in note 133).

${ }^{154}$ Cooter, 31 San Diego L Rev at 150, 157-59 (cited in note 133).

155 See Breyer, 92 Harv L Rev at 581-82 (cited in note 7); Richard B. Stewart, Economics, Environment, and the Limits of Legal Control, 9 Harv Envir L Rev 1, 9-20 (1985). See generally Robert W. Hahn and Robert N. Stavins, Incentive-Based Environmental Regulation: A New Era From an Old Idea?, 18 Ecol L Q 1, 7-12 (1991); Stewart, 46 Md L Rev at 104-11 (cited in note 135).

Under the pollution charge approach, the government might tax each pound of a particular water pollutant at a flat rate (or even an escalating rate). The source could then choose whether to discharge the pollutant and pay the tax or pay for the installation of controls to reduce taxable discharges. An economically rational source would invest in pollution control technologies up to the point at which the last dollar spent on pollution control reduced the total tax by just one dollar. The level of pollution control achieved would therefore depend upon the tax rate. 
ly, they might prefer what Derrick Bell calls a "Racial Preferences Licensing Act" under which the government would set targets for integration along various suspect criteria (for example, race, gender, religion, national origin) and allow employers to "trade" among themselves in a market for discrimination. ${ }^{156}$

\section{Antipathy toward centralized regulatory decision making.}

Although not as dualistic in their view of the economic world as the radical anti-interventionists, the free marketeers share their fear of collectivism to the extent that they oppose centralized regulatory decision making. Like the radical anti-interventionists, the free marketeers are skeptical about the ability of federal agencies to acquire sufficient information to write protective rules and standards. ${ }^{157}$ When intervention is justified, it should focus on the narrowest possible range of undesirable conduct and should be accomplished at the level of government closest to the regulated entities. ${ }^{158}$

\section{Close management of bureaucracies.}

Because they generally distrust bureaucracies, the free marketeers generally advocate tight centralized control over the rulemaking process. Justice Breyer, for example, has suggested that Congress create a superagency, modeled after the French Conseil d'Etat, composed of well educated generalists who would review agency regulations under an "arbitrary and capricious" standard

Under the marketable permit approach, the regulatory entity determines the total amount of a particular pollutant that may be emitted into the receiving medium and divides that amount into discrete units. The agency then creates a new form of property, sometimes called a marketable permit, that consists of the right to discharge one unit of the pollutant. The initial distribution of marketable permits can be determined in many ways, including, for example, an auction, a lottery, or a first-come-first-served queue. Once the program is implemented, no one may discharge the pollutant except pursuant to the rights evidenced by marketable permits. Marketable permits may be sold and purchased by entities that discharge the pollutant or by entities that elect not to discharge the pollutant in order to reduce pollution. A discharger may therefore elect to install pollution reduction technologies and sell its permits when the value of the permits exceeds the cost of the technology.

${ }^{156}$ Derrick Bell, Faces at the Bottom of the Well: The Permanence of Racism 47-64 (BasicBooks 1992). See also Cooter, 31 San Diego L Rev at 148-49 (cited in note 133). As an alternative to marketable rights to discriminate, the free marketeers suggest a tax subsidy approach that would require "each firm to pay a tax on 'excess' workers of the disfavored type and receive a subsidy for 'surplus' workers of the favored type." Id at 147.

157 See Breyer, 92 Harv L Rev at 571-73 (cited in note 7); Stewart, 9 Harv Envir L Rev at 20-22 (cited in note 155).

${ }^{158}$ See Alice Rivlin, Reviving the American Dream (Brookings 1992). 
of review. ${ }^{159}$ Less ambitious free marketeers suggest structural regulatory reforms that would institutionalize and to some degree intensify the regulatory review function currently performed by OMB. ${ }^{160}$

\section{Modern Mugwumps}

The recent search for substantive criteria to guide the exercise of governmental power has lead to a revival of "civic republicanism" in the law schools and elsewhere. ${ }^{161}$ That this term means different things to different advocates is both a strength and a weakness. Professor Cass Sunstein, one of its most prolific and articulate advocates, argues that modern civic republicanism is entirely consistent with the American tradition of liberalism and should therefore be called "liberal republicanism." Indeed, for Sunstein, civic republicanism is so universally encompassing as to be consistent with "certain forms of utilitarianism" that "place a high premium on political deliberation, prize political equality, and do not take existing preferences and distributions as the basis for social choice."163 At the same time, "the ideas of the New Deal reformation are highly compatible with liberal republicanism." "Sunstein also finds liberal republicanism broadly consistent with pragmatism and Aristotelianism. ${ }^{165}$ Apparently, many tribes can comfortably gather under the civic republican tent. ${ }^{166}$

159 Breyer, Breaking the Vicious Circle at 70-72 (cited in note 143).

${ }^{150}$ See George C. Eads and Michael Fix, Relief or Reform? Reagan's Regulatory Dilemma 99-105 (Urban Institute 1984); C. Boyden Gray, Presidential Involvement in Informal Rulemaking, 56 Tulane L Rev 863, 864-65 (1985); Christopher C. DeMuth and Douglas H. Ginsburg, White House Review of Agency Rulemaking, 99 Harv L Rev 1075, 1080-88 (1986); Philip J. Harter, Executive Oversight of Rulemaking: The President is No Stranger, 36 Am U L Rev 557 (1987).

161 Prominent civic republican theorists include Frank Michelman, Mark Seidenfeld, Suzanna Sherry, and Cass Sunstein.

${ }^{162}$ Cass R. Sunstein, Beyond the Republican Revival, 97 Yale L J 1539, 1566-71 (1988); Cass R. Sunstein, Administrative Substance, 1991 Duke L J 607, 612-16 \& n 17. See also Ackerman, 99 Yale $\mathrm{L} J$ at $484-85$ (cited in note 11) (endorsing Professor Sunstein's view).

${ }_{163}$ Sunstein, 1991 Duke $L J$ at $615-16$ (cited in note 162).

164 Id at 617.

165 Id at 616.

166 Bruce Ackerman also embraces the possibility of a liberal republicanism that conjoins late eighteenth-century notions of civic republicanism with what he views as a nonlibertarian strand of liberalism that rejects the notion of natural rights in property and contract and "insists that the foundation of personal liberty is a certain kind of political life-one requiring the ongoing exertions of a special kind of citizenry." Ackerman, 99 Yale $L \mathrm{~J}$ at 484 (cited in note 11 ). 
In their eagerness to adopt inclusive, centrist positions ${ }^{167}$ and in their hostility toward corruption in government, the new civic republicans resemble the nineteenth-century Liberal Republican Party and, more particularly, the Mugwumps, ${ }^{168}$ who bolted the Republican Party to vote for Grover Cleveland in 1884 out of revulsion at the loose political and business ethics of the day. ${ }^{169}$ Bearers of the civic republican tradition during the latter years of the nineteenth century, the Mugwumps hoped "to put the national interest, as well as the interests of civic improvement, above personal motives or political opportunism."170 But they were also members of a "cosmopolitan and educated elite" that stressed the values of professionalism and specialization in public affairs. ${ }^{171}$ They still believed in the sanctity of private property, ${ }^{172}$ and they were quite committed to the free market. ${ }^{173}$ Like their nineteenth-century counterparts, the modern mugwumps often see themselves on both sides of important substantive debates about the future of the regulatory state.

Although the modern mugwumps generally support federal regulation to prevent abuse of monopoly power, to allocate scarce commonly held resources, to secure equal employment opportunities, and to protect health and the environment, they are convinced that the existing adversarial approach to regulation has

${ }^{167}$ See William N. Eskridge, Jr. and Gary Peller, New Public Law Movement: Moderation as a Postmodern Cultural Form, 89 Mich L Rev 707, 764 (1991).

${ }_{168}$ The term "mugwump" was borrowed by editor Charles A. Dana from the Algonquian Indian word meaning "great men," but it nicely conveyed the image of a person sitting on a fence with his mug on one side and his wump on the other. See McFarland, ed, Mugwumps at 1 (cited in note 22).

${ }_{160}$ John G. Sproat, "The Best Men": Liberal Reformers in the Gilded Age 126-27, 13839 (Oxford 1968). The "Mugwumps" included college educated professionals from the upper strata of the towns and cities of the Northeast and (to a lesser extent) the Midwest, and "proper" businessmen like Charles Francis Adams and Edward Atkinson, along with a smattering of ministers and educators. Some had been members of the Liberal Republican coalition; others were more recent recruits, most of whom, like Louis D. Brandeis, came of age politically during the 1880 s and 1890 s. Their intellectual spokespersons included George William Curtis, editor of Harpers Weekly, and British import E.L. Godkin, founding editor of The Nation. See Sidney Fine, Laissez Faire and the GeneralWelfare State: A Study of Conflict in American Thought 1865-1901 49-51 (Michigan 1956); Eric F. Goldman, Rendezvous with Destiny 17-19 (Knopf 1952); Richard Hofstadter, The Age of Reform: From Bryan to FDR 137-39 (Knopf 1955); McFarland, ed, Mugwumps at 14 (cited in note 22).

130 Hofstadter, Age of Reform at 140 (cited in note 169 ).

171 McFarland, ed, Mugwumps at 9, 14 (cited in note 22).

172 Josephson, Robber Barons at 305 (cited in note 18); Sproat, Best Men at 9-10 (cited in note 169).

${ }^{173}$ Hofstadter, Age of Reform at 141-42 (cited in note 169); Sproat, Best Men at 8-9 (cited in note 169). 
failed. While the free marketeers grudgingly accept regulation, the modern mugwumps often invite it in principle, but soon tire of it in practice. On questions of cognitive and structural regulatory reform, the modern mugwumps align themselves fairly closely with the free marketeers, favoring liberal use of regulatory analysis and careful scrutiny of agency rule making by OMB.

Only in the area of procedural regulatory reform do the modern mugwumps depart greatly from their free marketeer colleagues. The modern mugwumps generally favor broadly participatory administrative decision making of the sort that encourages deliberative debate among regulators, regulatees, and regulatory beneficiaries. Although very reluctant to position themselves in debates over substantive regulatory reform, the modern mugwumps tend to side with the free marketeers because, like their nineteenth-century counterparts, they are still devoted to the free market paradigm.

\section{Building a civic community.}

In inviting full participation from the widest possible range of citizens and in insisting that all participants pay careful attention to the views of others, the modern mugwumps hope to reduce the level of alienation among citizens who do not share the same interests and goals. ${ }^{174}$ One of the strongest principles of civic republicanism is that public discourse must be about the collective interest and not about private greed. Modern mugwumps firmly believe that most citizens have a concept of the public interest that varies (perhaps substantially) from their own private interests. ${ }^{175}$ In civic republican deliberations about regulation, narrow appeals to protect existing companies from competition or regulatory burdens should be deeply discounted, because the underlying motivation is private avarice. Arguments about regulation should be about techniques that can advance the overall public good. ${ }^{176}$

174 Mark Seidenfeld, A Civic Republican Justification for the Bureaucratic State, 105 Harv L Rev 1512, 1533-34 (1992).

${ }^{175}$ Sunstein, 97 Yale L J at 1550 (cited in note 162); Seidenfeld, 105 Harv L Rev at 1536 (cited in note 174).

176 See Seidenfeld, 105 Harv L Rev at 1534-35 (cited in note 174). 


\section{Commitment to a virtuous citizenry.}

The modern mugwumps' high regard for civic virtue leads them beyond the focus of their nineteenth-century counterparts on political corruption to advocate an affirmative role for government in fostering a virtuous citizenry. To its proponents, civic republicanism is an alternative to raw pluralism in which interest groups advancing their own economic interests vie for power in the political and regulatory process. ${ }^{177}$ Pluralism is open to the possibility that "bad preferences" will prevail, and it accepts without question "preferences [that] are formed against the backdrop of disparities in power and limitations in both opportunities and information." ${ }^{.178}$ By contrast, the modern mugwumps believe that law can shape human preferences and not merely reflect them. ${ }^{179}$ Citizens who participate in the political process should come out the better for it, and not simply in material terms. They should want better things for themselves and society. ${ }^{180}$ If popular culture has produced a lazy and uninformed citizenry, it may be due to some correctable failure of the legal regime. By regulating certain kinds of private conduct (for example, television programming and advertising), the government can help citizens shed their self-interested self-delusions and meet their civic obligations. ${ }^{181}$

177 Sunstein, 97 Yale L J at 1544 (cited in note 162). See also Michelman, 97 Yale L J at 1503 (cited in note 11).

178 Sunstein, 97 Yale L J at 1543-44 (cited in note 162).

179 See Cass R. Sunstein, Republicanism and the Preference Problem, 66 Chi Kent L Rev 181, 181, 203 (1990); Sunstein, 97 Yale $L J$ at 1546-47 (cited in note 162). The idea that law and politics can shape private preferences is not at all unique to the modern mugwumps. See Eskridge and Peller, 89 Mich L Rev at 748 (cited in note 167) (maintaining that a broader group of public law scholars than just civic republicans reject the notion of exogenous preferences); David Frum, Dead Right 102 (BasicBooks 1994) (quoting neoconservative Irving Kristol urging the state to take "a degree of responsibility for helping to shape the preferences that the people exercise in a free market-to 'elevate' them, if you will."). See also text accompanying notes 267-69 (position of unrepentant protectionists on exogenous preferences).

${ }^{180}$ Seidenfeld, 105 Harv L Rev at 1537 (cited in note 174) ("By informing citizens about others' conceptions of the public interest and by revealing to them how their own conceptions might harm others, the deliberative process can help educate citizens and unmask self-delusions.”).

${ }^{181}$ See Cass R. Sunstein, Democracy and the Problem of Free Speech 113-14 (Free Press 1993). 


\section{Deliberative decision making.}

Central to the modern mugwump vision of the good society is the concept of "deliberative" democracy, ${ }^{182}$ in which politics consists of enlightened debates among a broadly inclusive group of well informed citizens expressing a wide diversity of views about important social problems. ${ }^{183}$ Unlike the nineteenth-century Liberal Republicans, who were inclined to exclude dissenting voices from deliberations, ${ }^{184}$ the modern mugwumps would urge the majority participants to listen carefully to and empathize with those in the minority. ${ }^{185}$ The substantive result reached at the end of the process is often not as important as the clarity of the debate and fairness of the process. ${ }^{186}$ Self-interested positions "should be revisable in light of collective discussion and debate, bringing to bear alternative perspectives and additional information," ${ }^{\prime 187}$ and hardened positions should soften. ${ }^{188}$ If a lack of relevant information prevents a consensus, the process should be held in abeyance while more facts are gathered and incorporated into the deliberative dialogue.

As more agreed-upon facts become available, the disputants are more likely to reach an accommodation. ${ }^{189}$ Ultimately, the "transformative power of politics" will "enable[ ] the polity to reach consensus about the common good." ${ }^{190}$ When consensus proves elusive, the decision maker must give good reasons for his or her resolution of the debate, explaining how the outcome advances the common good. ${ }^{191}$ The losers can take comfort in the fact that they received a fair hearing and can rest assured that they can win tomorrow's struggle if their cause is just and their arguments persuasive.

182 Seidenfeld, 105 Harv L Rev at 1528-30 (cited in note 174); Michelman, 97 Yale L J at 1513-14 (cited in note 11).

${ }_{183}$ Cass R. Sunstein, Well-Being and the State, 107 Harv L Rev 1303, 1303 (1994); Seidenfeld, 105 Harv L Rev at 1528 (cited in note 174) ("[C]ivic republicanism embraces an ongoing deliberative process, inclusive of all cultures, values, needs, and interests, to arrive at the public good.").

184 Michelman, 97 Yale L J at 1505-06 (cited in note 11).

185 Eskridge and Peller, 89 Mich L Rev at 786 (cited in note 167); Seidenfeld, 105 Harv L Rev at 1534 (cited in note 174); Sunstein, 97 Yale L J at 1556 (cited in note 162).

${ }^{186}$ Eskridge and Peller, 89 Mich $\mathrm{L}$ Rev at 783 (cited in note 167); Michelman, 97 Yale

$L \mathrm{~J}$ at 1526-29 (cited in note 11).

187 Sunstein, 97 Yale L J at 1549 (cited in note 162).

188 See id at 1555 .

189 Eskridge and Peller, 89 Mich I Rev at 777 (cited in note 167).

190 Seidenfeld, 105 Harv $L$ Rev at 1529 (cited in note 174). See also Sunstein, 1991 Duke $L \mathrm{~J}$ at 613 (cited in note 162).

191 Seidenfeld, 105 Harv L Rev at 1529-30 (cited in note 174). 
4. Commitment to rational analysis.

The civic republican belief in deliberative democracy is reinforced by a commitment to rational analysis. If the republican multilogue is only a policy debate about how society ought to be arranged, then any hope for consensus will normally fade as it becomes clear that the participants have widely divergent and nonverifiable views about the answers to empirical questions that are often at the heart of policy discussions. Although answering critical empirical questions is always exceedingly difficult and sometimes impossible, modern mugwumps are especially fond of applying quantitative models to the bits of data that do exist in the hope of reaching a tentative consensus pending the arrival of new information. Thus, in the area of health and environmental regulation, modern mugwumps tend to agree with the free marketeers on the need for cognitive regulatory reforms like greater use of quantitative risk assessment techniques. ${ }^{192}$ The modern mugwumps also tend uncritically to accept the free marketeer critiques of existing regulatory programs when they are backed up with impressive quantitative tables and charts. Although they probably know that such quantitative demonstrations are often crafted out of whole cloth by persons advancing particular policy positions (or even private pecuniary interests), they still rely upon these impressive looking studies to support their "neutral" arguments for substantive regulatory reform. ${ }^{193}$

5. Tolerance for disparities in wealth and insistence on freedom from desperate conditions.

With some ambivalence, the modern mugwumps share the tolerance of the radical anti-interventionists and the free marketeers for large disparities in income and wealth among the citizenry. ${ }^{194}$ Such disparities advance three important republican goals: "promoting liberty; providing incentives for productive work; and rewarding and recognizing individual achievement and excellence. ${ }^{195}$ The modern mugwumps, however, believe that each citizen is entitled to the basic necessities of life- "adequate

${ }_{192}$ See Richard H. Pildes and Cass R. Sunstein, Reinventing the Regulatory State, 62 U Chi L Rev 1, 72 (1995).

${ }_{193}$ See Cass R. Sunstein, Paradoxes of the Regulatory State, 57 U Chi L Rev 407, 41819 (1990).

194 Sunstein, 1991 Duke L J at 613-14 (cited in note 162) ("[T]he political creed of economic egalitarianism is foreign to the liberal republicanism of American public law.").

195 Id at 614. 
food, shelter, police protection, [and] medical care."196 This commitment is very much at odds with the radical anti-interventionist position that private markets should allocate virtually all resources. ${ }^{197}$

\section{Equality of opportunity.}

The modern mugwumps believe that all citizens should enjoy equality of opportunity, not only in the political sphere, but also in their pursuit of private gain. ${ }^{198}$ Although government cannot guarantee equality of outcome (which would in any event be inconsistent with the modern mugwump toleration for wide disparities in wealth), it can "ensure that education is available to all," "design regulatory systems that promote awareness and understanding of public issues," and "create training and other programs to give solid prospects to people born in average or below-average conditions." 199 This right, like the entitlement to freedom from desperate conditions, apparently flows from a republican commitment to broad participation by well informed citizens in the great deliberations in the public sphere.

\section{Limited commitment to the market as a benchmark.}

Though denying the radical anti-interventionist view that property rights are "prepolitical,"200 the modern mugwumps still retain a healthy respect for the institution of private property as a vital protection against governmental abuse and as a vehicle for achieving greater prosperity. ${ }^{201}$ Like the free marketeers, the modern mugwumps believe that government regulation is necessary primarily to fix broken markets. ${ }^{202}$ The modern mugwumps, however, are willing to entertain the possibility that civic

196 Id.

197 See text accompanying notes 129-30.

198 Sunstein, 1991 Duke L J at 615 (cited in note 162).

199 Id.

200 Sunstein, 97 Yale I J at 1551 (cited in note 162).

201 Sunstein, 1991 Duke L J at 612 n 20 (cited in note 162) ("A liberal republican would emphasize that private property is a creation of legal rules, rather than a prepolitical right; but liberal republicanism certainly does not, for this reason, disparage the institution of private property."). It is not clear whether the modern mugwumps would join the radical anti-interventionists in refusing to draw a distinction between economic rights and other human rights.

202 The free play of the marketplace, however, is subject to the previously mentioned constraints that every citizen has a right to the basics of life and to an equal opportunity to pursue wealth in the marketplace. 
deliberation will lead to agreement on intervention in at least some cases in which citizens prefer to vote differently with their ballots than their pocketbooks. ${ }^{203}$

\section{Cost-benefit test for governmental intervention.}

The modern mugwumps share the free marketeers' affinity for the cost-benefit test as a substantive decisional criterion, but for somewhat different reasons. Rather than relying exclusively upon efficiency as the rationale, the modern mugwumps find that it nicely advances the sense of "proportionality" that derives from general republican principles. ${ }^{204}$ Rational cost-benefit analysis, with its emphasis on quantitative techniques, offers the possibility of a "neutral" solution that reflects an appropriate balancing of all the competing societal interests. Hence, the modern mugwumps would not allow health and environmental agencies to require reductions in levels of human exposure to toxic pollutants below some level at which the pollutants pose de minimis risks, because the benefits of addressing those risks can rarely justify the costs. ${ }^{205}$

\section{Market-based solutions to social problems.}

Like the free marketeers and radical anti-interventionists, the modern mugwumps oppose "command-and-control" approaches toward achieving regulatory goals. ${ }^{206}$ Beyond the free marketeers' efficiency arguments against technology-based commands, the modern mugwumps worry that a system focusing on obscure and arcane questions about the feasibility of particular technologies effectively excludes ordinary citizens from the debate and turns it over to special interest groups. The modern mugwumps therefore agree with the free marketeers and radical antiinterventionists that market-oriented techniques, like effluent charges and marketable pollution permits, are generally the best vehicles for reaching regulatory goals. ${ }^{207}$

203 Sunstein, 1991 Duke L J at 621 (cited in note 162) ("[P]olitical action can and sometimes should overcome existing private preferences and beliefs.").

${ }^{204}$ Sunstein, 48 Stan L Rev at 252-53 (cited in note 11).

${ }^{205}$ See Sunstein, 97 Yale I J at 1583 (cited in note 162) (suggesting that courts be empowered to declare invalid regulations that address only de minimis risks).

${ }^{206}$ Seidenfeld, 105 Harv L Rev at 1575 (cited in note 174); Sunstein, 1991 Duke L J at $627-29$ (cited in note 162).

207 Sunstein, 1991 Duke L J at 629-42 (cited in note 162). 


\section{Decentralized decision making.}

Like the free marketeers, the modern mugwumps favor devolution of governmental power to small, decentralized governmental decision-making units, ${ }^{208}$ but they do so not so much out of concern for efficiency as out of a conviction that republican deliberative processes work better in smaller communities. ${ }^{209}$ The result, however, is the same-a general antipathy toward large centralized bureaucracies. ${ }^{210}$ In the modern mugwump view, large governmental units invite corruption and destroy social homogeneity. ${ }^{211}$

\section{Close management of bureaucracies.}

Some modern mugwumps agree with the free marketeers that Congress should grant broad authority to OMB to oversee policy-making in the executive branch, so long as it is done in an open and accountable fashion. ${ }^{212}$ The president is elected by the entire country and is therefore likely to take the interests of all citizens, rather than parochial pressures, into account. Likewise, the president is in the best position to coordinate public policy and reduce inefficient duplication. ${ }^{213}$ Finally, presidential management has the greatest potential for "allowing the government to respond to shifts in public opinion and decreasing the likelihood that politics will become routinized and heavily bureaucratized. ${ }^{\text {.14 }}$

\section{Good Government Reinventionists}

The good government reinventionists are firm believers in the potential of government to solve pressing and persistent social problems. ${ }^{215}$ Unlike the radical anti-interventionists, they

208 Sunstein, 97 Yale I J at 1578 (cited in note 162).

${ }^{209}$ See Cass R. Sunstein, Constitutionalism After The New Deal, 101 Harv L Rev 421, 506-08 (1987).

210 An exception to this generalization may be Professor Seidenfeld, who argues convincingly that federal bureaucracies are ideal fora for republican deliberation, because they "fall between the extremes of the politically over-responsive Congress and the overinsulated courts." Seidenfeld, 105 Harv L Rev at 1542 (cited in note 174).

211 Sunstein, 97 Yale I $J$ at 1556 (cited in note 162).

212 Sunstein, 101 Harv L Rev at 452-63 (cited in note 209). Not all civic republicans would assign a broader review role to OMB. Professor Seidenfeld, for example, cautions against assigning too great a review role to OMB. Seidenfeld, 105 Harv L Rev at 1552 (cited in note 174).

${ }^{213}$ Sunstein, 101 Harv L Rev at 453 (cited in note 209).

214 Id.

${ }^{215}$ The founding fathers of the good government reinventionists are David Osborne 
do not accept as a given the existing distribution of property, nor do they agree with the free marketeers that allocative efficiency is the primary reason for regulating private conduct. But they recognize that governmental solutions require large and complex bureaucracies. Applying what they call a "new paradigm," they want to "reinvent" government to deliver important governmental protections with a minimum of bureaucratic delay and red tape. Like the modern mugwumps, they favor good government, sound analysis of social problems, and market-oriented approaches to implementing policy goals. They also share the modern mugwumps' inclination to leave matters to private arrangements entered into after the government has done what is necessary to reduce market imperfections and to secure equal bargaining power.

\section{Better tools for better government.}

In their search for ways to make government work better, the good government reinventionists focus almost exclusively upon procedural, structural, and means-oriented substantive regulatory reform. ${ }^{216}$ Recognizing that the resources available to address regulatory problems are scarce, they urge agencies to set wise priorities using available quantitative tools. ${ }^{217}$ They generally favor information disclosure and consumer education projects as alternatives to the costly and time-consuming rule-making process, ${ }^{218}$ and procedural reforms to speed up internal agency decision making and interagency regulatory review processes. ${ }^{219}$

and Ted Gaebler, but others were making similar points before Osborne and Gaebler coined the term "reinventing government." I would also place in this category much of the recent scholarly work of Donald Elliott, Susan Rose-Ackerman, and Paul Weiler.

${ }_{216}$ See David Osborne and Ted Gaebler, Reinventing Government: How the Entrepreneurial Spirit is Transforming the Public Sector xxi (Addison-Wesley 1992) ("The central failure of government today is one of means, not ends."). See also Charles T. Goodsell, Did NPR Reinvent Government Reform?, Pub Manager 7, 7 (Sept 22, 1993) (The phrase "reinvent government" does not denote a substantive outcome, but rather "expresses a generalized aspiration.").

217 See Carnegie Commission on Science, Technology, and Government, Risk and the Environment: Improving Regulatory Decision Making 33-35, 76-82 (Carnegie 1993).

${ }^{218}$ Susan Rose-Ackerman, Progressive Law and Economics-And the New Administrative Law, 98 Yale L J 341, 358 (1988).

${ }^{219}$ Gore, From Red Tape to Results at $41-46$ (cited in note 78). 


\section{Empowering citizens.}

The good government reinventionists also resemble the modern mugwumps in their desire to empower ordinary citizens and involve them in the governing process. ${ }^{220}$ Hence, they support procedural regulatory reforms like expanding opportunities for public participation early in the rule-making process and reducing opportunities for powerful outsiders to affect the outcomes of rule-making initiatives through closed-door sessions with the staffs of the agencies and OMB. ${ }^{221}$ But they also want to give ordinary citizens more power over their everyday lives in the private sector. Hence, they would limit, though not eliminate, the employment-at-will doctrine that the radical anti-interventionists find so appealing. Professor Weiler, for example, would require an employer to have good cause to fire "career employees" with whom the employer, over the years, has implicitly promised to maintain a continuing employment relationship, ${ }^{222}$ but he would not require good cause to fire most blue collar workers who lack legitimate long-term expectations. ${ }^{223}$

\section{Total quality management.}

One of the prominent ideas of the good government reinventionists is the notion that bureaucrats, like all good entrepreneurs, should attempt to meet the needs of their "customers." 224 A regulatory agency's customers are the citizens that the agency's regulations are meant to protect, not the regulated industries and public interest groups, and not even the congressional committee staff or the managers in OMB. The customer concept is meant to address directly the perception that regulatory agencies are composed of arrogant bureaucrats more concerned about their own turf and petty prerogatives than about the public interest.

${ }_{220}$ See id at 3; Osborne and Gaebler, Reinventing Government at 19, 73-75 (cited in note 216).

221 Gore, From Red Tape to Results at 38-39 (cited in note 78).

222 Paul C. Weiler, Governing the Workplace: The Future of Labor and Employment Law 102 (Harvard 1990). See also Samuel Issacharoff, Contracting for Employment: The Limited Return of the Common Law, 74 Tex L Rev 1783 (1996).

${ }_{223}$ Weiler, Governing the Workplace at 102 (cited in note 222). Compare Matthew W. Finkin, Back to the Future of Labor Law, 32 Wm \& Mary I Rev 1005, 1012 (1991) (reviewing Weiler's Governing the Workplace and drawing white-collar/blue-collar distinction).

224 Osborne and Gaebler, Reinventing Government at 166-94 (cited in note 216). 
The concern for customers translates into "total quality management" ("TQM") within the bureaucracy. Under the TQM concept, "the customers are the most important people for an organization; those who serve customers directly are next; and management is there to serve those who serve customers. ${ }^{225}$ The TQM idea has implications for structural regulatory reform. It suggests that OMB should play a less constraining role with respect to regulatory agency development and promulgation of rules. ${ }^{226}$ It also suggests that agencies like OSHA should allow regional officials to experiment with cooperative programs that achieve lower workplace injury rates without acrimonious wall-to-wall inspections and citations for "nit-picking" violations. ${ }^{227}$

\section{Emphasis on prevention.}

The good government reinventionists adopt a future-oriented emphasis on preventing social problems before they become too large to deal with in an efficient and effective manner. ${ }^{228}$ Rather than spending billions of dollars cleaning up abandoned hazardous waste dumps, the regulatory system should adopt pollution prevention programs to stop certain toxic substances from being generated in the first place. The good government reinventionists also support actions like EPA's phaseout of leaded gasoline and efforts by several states and localities to ban polystyrene cups. ${ }^{29}$

5. Rejection of the market benchmark and cost-benefit decision criteria.

When it comes to demanding that regulations be justified by proof of market failure, the good government reinventionists part company with the free marketeers and modern mugwumps. The good government reinventionists recognize that government sets the rules of the marketplace and that government intervention may be justified on fairness, equity, or other grounds apart from

225 Id at 172.

${ }_{226}$ See E. Donald Elliott, TQM-ing OMB: Or Why Regulatory Review Under Executive Order 12,291 Works Poorly and What President Clinton Should Do About It, 57 L \& Contemp Probs 167, 175-81 (1994).

${ }^{227}$ Gore, Common Sense Government at 26-27 (cited in note 78).

228 See generally Osborne and Gaebler, Reinventing Government at 219-49 (cited in note 216) (describing and advocating "anticipatory government").

220 See id at 227-29. 
broken markets. ${ }^{230}$ For similar reasons, the good government reinventionists do not insist that all important regulations pass a cost-benefit test. Cost-benefit analysis is useful in identifying and evaluating regulatory options, but ultimately the test should be whether the option represents good public policy as reflected in the agency's organic statute, not whether quantified benefits are larger than quantified costs. Good public policy incorporates considerations beyond simple utilitarianism. ${ }^{231}$ At the same time, however, the good government reinventionists would demand that regulations be "cost-effective" in the sense that roughly the same resources should be expended to secure a nonmonetizable benefit (for example, a life saved) in one regulatory context as in another. ${ }^{232}$

\section{Market-based solutions to social problems.}

Like the free marketeers and the modern mugwumps, the good government reinventionists are generally opposed to command-and-control approaches to achieving regulatory goals. ${ }^{233}$ They argue that traditional regulatory commands are very difficult to write, are not always vigorously enforced, and usually fail to affect the underlying incentives of the regulated entities. ${ }^{234}$ In the context of occupational safety and health, for example, the good government reinventionists are convinced that OSHA cannot possibly acquire sufficient information to prescribe technology-based standards for every risky workplace, and they therefore advocate greater use of collective bargaining and mandatory safety committees in nonunionized workplaces. ${ }^{235}$ Although the good government reinventionists do not accept the unimpeded market as the appropriate benchmark for regulation, they favor market-oriented techniques that allow "public leverage to shape private decisions to achieve collective goals." ${ }^{236}$ For example, Professor Mashaw concludes that allocative efficiency alone prob-

230 See id at 290-92, 298.

231 Rose-Ackerman, 98 Yale $\mathrm{L} J$ at 344 (cited in note 218).

232 Id at 359.

${ }^{233}$ See Osborne and Gaebler, Reinventing Government at 301-05 (cited in note 216); Gore, From Red Tape to Results at 11 (cited in note 78).

${ }^{234}$ See Osborne and Gaebler, Reinventing Government at 300-01 (cited in note 216).

235 Weiler, Governing the Workplace at 155-56, 181-85 (cited in note 222); Paul Weiler and Guy Mundlak, New Directions for the Law of the Workplace, 102 Yale I J 1907, 191415 (1993).

${ }^{236}$ See Osborne and Gaebler, Reinventing Government at 284 (cited in note 216) (emphasis omitted). 
ably does not justify forcing employers to spend large sums of money on accommodating the disabled, but he still believes that facilitating the participation of disabled persons in constructive endeavors is warranted on other moral and economic grounds. ${ }^{237} \mathrm{He}$ therefore suggests a novel reinventionist regime of quotas and marketable "rights to discriminate."238

\section{Decentralized decision making.}

Like the free marketeers and the modern mugwumps, the good government reinventionists question the ability of large centralized bureaucracies to regulate effectively. ${ }^{239}$ In their view, decentralized institutions are more effective, more innovative, more flexible, and more productive than centralized institutions. ${ }^{240}$ Perhaps most importantly, they believe that people generally trust the units of government closest to them. ${ }^{241}$ Therefore, their rule of thumb is, "unless there is an important reason to do otherwise, responsibility for addressing problems should lie with the lowest level of government possible." ${ }^{242}$ However, they concede much more readily than the free marketeers, and somewhat more readily than the modern mugwumps, the need for federal leadership in the area of environmental regulation and in many other areas in which the obligation to protect the public "transcend[s] the capacities of state and local governments."243

\section{Close management of bureaucracies.}

For the good government reinventionists, effective management is the way to get more bang for the taxpayers' buck. Therefore, like the modern mugwumps, they support central review mechanisms (for example, OMB review) that exert management control over the regulatory bureaucracies. They are more con-

237 Jerry L. Mashaw, Against First Principles, 31 San Diego L Rev 211, 220-25 (1994). Professor Mashaw very persuasively rejects the radical anti-interventionist call for the repeal of Title VII of the Civil Rights Act of 1964. Id at 225-39.

${ }^{238}$ Id at 232-34.

239 See Osborne and Gaebler, Reinventing Government at 11-12 (cited in note 216) ("Our thesis is simple: The kind of governments that developed during the industrial era, with their sluggish, centralized bureaucracies, their preoccupation with rules and regulations, and their hierarchical chains of command, no longer work very well.").

${ }^{240}$ See id at $252-53$.

${ }^{241}$ See id at 277.

$242 \mathrm{Id}$.

${ }^{243} \mathrm{Id}$. 
cerned, however, with coordination to avoid duplication and overlap than with avoiding parochial power plays. ${ }^{244}$

9. Emphasis on voluntarism and negotiation.

The good government reinventionists believe that most citizens and corporations mean well and will attempt in good faith to "do the right thing." 245 Therefore, they prefer voluntary approaches in which regulatory agencies make public appeals to regulatees to mind their civic responsibilities and offer some mild positive or negative inducement to encourage them to adopt protective measures voluntarily. ${ }^{246}$ Voluntary programs are generally not designed to achieve specific regulatory goals or to induce regulatees to behave in any particular ways. Their aims are usually to persuade private entities to change their standard operating procedures in ways that steer things generally in the right direction.

Another favorite technique of the good government reinventionists is the procedural regulatory reform called "regulatory negotiation." As discussed earlier, this procedure encourages discussion and deliberation amongst the stakeholders prior to beginning the standard rule-making process. ${ }^{247}$ In a similar vein, they advocate that agencies make greater use of alternative dispute resolution techniques (for example, mediation, settlement judges, and mandatory arbitration) at the enforcement stage. ${ }^{248}$

The good government reinventionists also offer governmentmonitored bargaining exercises in the private sector as alternatives or supplements to regulation. In particular, they would reinvigorate collective bargaining as a tool for establishing workplace practices in both unionized and nonunionized workplaces. ${ }^{249}$ Professor Weiler, for example, offers proposals to equalize the bargaining power of workers and employers through greater protections for, and increased awards to, victims of employer retaliation for organizational activities and strikes. ${ }^{250}$

244 Gore, From Red Tape to Results at 32-34 (cited in note 78).

${ }_{245}$ Gore, Common Sense Government at 33 (cited in note 78).

${ }^{246}$ See U.S. Likely to Stabilize CO2 Emissions by End of Century, Reilly Tells Committee, 23 Envir Rptr (BNA) 1113, 1113 (1992) (voluntary program to reduce emissions of greenhouse gases); 'Green Lights' Pacts Between U.S. Firms, EPA Could Cut Emissions by 235 Million Tons Annually, 21 Envir Rptr (BNA) 1705, 1705 (1991) (voluntary program to reduce energy consumption and reduce emissions of greenhouse gases).

${ }^{247}$ See text accompanying note 61 .

${ }^{248}$ Gore, Common Sense Government at 95 (cited in note 78).

249 Weiler, Governing the Workplace at ch 4 (cited in note 222).

250 Id at 233-73; Weiler and Mundlak, 102 Yale L $J$ at 1916-20 (cited in note 235). Pro- 
For nonunionized workplaces, the good government reinventionists suggest that federal agencies like the NLRB and OSHA experiment with joint labor-management committees as vehicles for addressing disputes that arise in the workplace. ${ }^{251}$

\section{E. The Unrepentant Protectionists}

Although much of the current political rhetoric assumes that most of the regulatory programs enacted during the New Deal and the civil rights-public interest eras have failed, those programs still have many defenders. Franklin Roosevelt and Martin Luther King may be dead, but Ralph Nader is alive and well, ${ }^{252}$ and statutes like the Clean Air Act and the Americans With Disabilities Act still have many defenders in academia and in the political world. I will refer to those who are prepared to defend existing interventionist legislation and to offer additional interventionist solutions to existing social problems as "unrepentant protectionists." 253

The enactment of the Clean Air Act Amendments of $1990^{254}$ and the Civil Rights Act of $1991^{255}$ strongly suggests that the American public continues to support government intervention as a solution to social problems. The fact that very little protective legislation is likely to emerge from the 104th Congress does not imply that the civil rights-public interest movement is dead,

fessor Weiler concludes that the recent precipitous decline in employee participation in unions has resulted from fierce employer resistance to unions, including flagrantly unlawful union-busting activities and "a few explicitly one-sided restraints on union organizing efforts" in the NLRA, "most . . . traceable to the Taft-Hartley amendments of 1947." Weiler, Governing the Workplace at 111-18, 228, 233-41 (cited in note 222). See also Weiler and Mundlak, 102 Yale L J at 1912-13, 1916 (cited in note 235); Paul C. Weiler, Hard Times for Unions: Challenging Times for Scholars, 58 U Chi L Rev 1015, 1016-32 (1991) (summarizing and defending the arguments made in Governing the Workplace).

251 See Ray Marshall, Unheard Voices: Labor and Economic Policy in a Competiive World 156-85 (BasicBooks 1987); Osborne and Gaebler, Reinventing Government at 263-65 (cited in note 216); Weiler and Mundlak, 102 Yale $\mathrm{L} J$ at 1922-23 (cited in note 235).

${ }^{252}$ See Anthony Ramirez, Consumer Crusader Feels a Chill in Washington, NY Times Section 3 at 1, 10-11 (Dec 31, 1995) (describing Nader's recent work on consumer protection and lobbying reform).

${ }^{253}$ As the reader has by now no doubt surmised, I would place myself in the unrepentant protectionist category. I would also include within the unrepentant protectionist category Nicholas Ashford, Mary Becker, Derrick Bell, Cynthia Estlund, Robert Glicksman, Oliver Houck, Mark Kelman, Howard Latin, Richard Lazarus, Zygmunt Plater, Mark Sagoff, Sidney Shapiro, Jack Getman, and David Vladeck.

25t Pub L No 101-549, 104 Stat 2399, codified at 42 USC §§ 7401-7671q (1988 \& Supp 1993).

${ }^{255}$ Pub L No 102-166, 105 Stat 1071, codified as amended at 29 USC §§ 1981 et seq (1988 \& Supp 1993). 
though it does suggest that some retrenchment and re-examination may be in order.

To the obvious retort that relatively strong equal opportunity, environmental, and consumer protection laws have been on the books for at least two decades without achieving significant success, the unrepentant protectionists have at least three responses. First, the civil rights and public interest laws have in fact succeeded. The civil rights laws have been effective in protecting women and minorities from invidious discrimination, ${ }^{256}$ and the pollution control and worker protection laws have brought about steady improvements in environmental quality and worker health and safety. ${ }^{257}$ Second, to the extent that they have not worked, the fault lies with the bitter resistance of regulatees and their allies, and with the meager resources available to regulatory agencies that have made it impossible to overcome this resistance. To add insult to injury, in recent times, Congress has reduced agency rule-making budgets while simultaneously increasing regulatory demands. ${ }^{258}$ Finally, the unrepentant protectionists are convinced that beneficiaries of regulatory programs would have suffered more if the country had adhered to a nineteenth-century laissez-faire model, and they are confident that a return to such a model would drastically exacerbate the problems. ${ }^{259}$

\section{Importance of symbolic statements.}

The unrepentant protectionists are very aware of the roles that myth and symbolism play in governance. They agree with the modern mugwumps that civic debate can reorder private preferences, but they place more faith in the power of symbolic action than in reasoned dialogue. The "million man march" on Washington, D.C., for example, was not about dialogue, nor was it merely an attempt by an interest group to pressure a reluctant

${ }^{256}$ See Weiler and Mundlak, 102 Yale $L \mathrm{~J}$ at 1915 (cited in note 235).

257 See Gregg Easterbrook, A Moment on Earth: The Coming Age of Environmental Optimism xiii-xv, 471-72 (Viking 1995) ("Environmental protection is the leading success story of postwar liberalism."). The unrepentant protectionists find the modern mugwumps far too willing to accept at face value studies by free marketeers purporting to demonstrate that "regulation has imposed enormously high costs for speculative benefits" and that "regulation has sometimes aggravated the very problem that it was designed to solve." Sunstein, 1991 Duke L J at 625 (cited in note 162).

${ }^{258}$ See Greider, Who Will Tell the People at 109-22 (cited in note 24).

259 See Nancy E. Dowd, Liberty vs. Equality: In Defense of Privileged White Males, 34 Wm \& Mary L Rev 429, 482 (1993). 
Congress into giving it a larger slice of the economic pie. It was intended to make a powerful symbolic appeal to African-American men to take greater responsibility for themselves and the people they love and to broadcast a similar symbolic message to the general public that African-American men demand greater respect from their communities.

The strong concern that unrepentant protectionists have for the role that symbolism can play in shaping public attitudes leads them to oppose some market-oriented strategies. ${ }^{260}$ For example, unrepentant protectionists are sometimes heard to complain that a system of effluent charges to reduce water pollution merely grants companies a "license to pollute." ${ }^{261}$ Similarly, unrepentant protectionists oppose suggestions that companies be allowed to establish a market in "rights to discriminate" against the disabled, even when the market would function only to reallocate mandatory hiring quotas. ${ }^{262}$ Although it is possible that such a vehicle would waste far fewer resources than a statute that simply required all employers to take reasonable steps toward accommodating the disabled, the symbolic message that the ability to avoid associating with disabled people was on sale to the highest bidder (or that the disabled would find employment only with those least able to afford the price of being rid of them) would constitute a powerful negative statement about society's regard for persons with disabilities.

\section{Narrow view of property rights.}

The unrepentant protectionists deny the radical anti-interventionist position that property rights are prepolitical and that historical inequities in the distribution of property are best left undisturbed. ${ }^{263}$ Since government defined those rights initially, government can redefine those rights if necessary to protect some of its citizens or commonly shared resources from the destructive activities of others. The fact that the common law courts of the

${ }^{260}$ See Steven Kelman, What Price Incentives?: Economists and the Environment 27 (Auburn House 1981).

261 Id at 44-46.

${ }^{262}$ See Steven B. Epstein, In Search of a Bright Line: Determining When an Employer's Financial Hardship Becomes "Undue" Under the Americans with Disabilities Act, 48 Vand L Rev 391, 399 n 26 (1995) ("Professor Mashaw's solution of bartering employment of disabled workers for cash harkens back to a day when slaves were auctioned at the public square.").

${ }^{263}$ See Lawrence C. Becker, Rent Control is Not a Taking, 54 Brooklyn L Rev 1215, 1216 (1989) (critiquing Professor Epstein's anti-interventionist position). 
late nineteenth century recognized a landowner's right to destroy the habitat of endangered species is, in their view, no reason to insist that any late twentieth-century limitation on those rights is a compensable taking. ${ }^{264}$ They are not persuaded by the radical anti-interventionists that government interference with property rights will automatically put all human rights at risk. ${ }^{265}$ Times change, and so do property rights. ${ }^{266}$

\section{Rejection of the market benchmark.}

The unrepentant protectionists do not agree with the radical anti-interventionists and the free marketeers that the broken market rationale is the only appropriate basis for government intervention. Like the modern mugwumps, they reject the assumption that individual preferences expressed in the marketplace are exogenous to the social and political context. ${ }^{267}$ Consumer preferences may govern markets, but the institutions that shape those preferences include the family, the school, the church, the entertainment industry, the mass media, and (primarily through the latter two vehicles) the marketplace itself. While the marketplace shapes preferences, the public sector shapes the preferences that are reflected in the marketplace. Law therefore has a role to play in bringing about a just society because law played a role in bringing about the injustices. ${ }^{268}$

The unrepentant protectionists further refuse to adopt economic freedom and efficiency as "meta-values" that effectively trump all other values in public policy-making. Concern for the welfare of endangered species or for future generations of humans cannot be captured in a regulatory system in which maximizing economic efficiency is the primary goal. ${ }^{269}$ Similarly, the radical anti-interventionists' devotion to economic freedom and the free marketeers' commitment to economic efficiency belittle the concerns for fairness and equality of opportunity that under-

${ }^{264}$ See Joseph L. Sax, Takings, 53 U Chi L Rev 279, 289-91 (1986).

265 See Richard J. Lazarus, Debunking Environmental Feudalism: Promoting the Individual Through the Collective Pursuit of Environmental Quality, 77 Iowa L Rev 1739, 1756-57 (1992).

${ }_{266}$ See Becker, 54 Brooklyn L Rev at 1216 (cited in note 263).

267 Eskridge and Peller, 89 Mich $L$ Rev at 748, 778 (cited in note 167).

268 Id at $748,777$.

${ }^{269}$ See Mark Sagoff, The Principles of Federal Pollution Control Law, 71 Minn L Rev 19, 55-68 (1986). 
lie fair employment laws. ${ }^{270}$ If necessary, efficiency must suffer in order that society may be more diverse and open.

\section{Predisposition toward protection.}

The unrepentant protectionists believe that Congress enacted most regulatory statutes to protect some citizens from the adverse consequences of the profit-maximizing activities of corporations and other citizens. In the context of the employment relationship, the unrepentant protectionists stress the reality of unequal bargaining power. ${ }^{271}$ Employees who have faithfully worked for years at a job deserve more than a brief citation to the nineteenth-century employment-at-will doctrine when a corporate rearrangement results in the elimination of their jobs. Fairness demands more than a pink slip when a supervisor decides that he just doesn't like an employee's attitude. To recognize an employer's right to fire an employee for bad reasons or no reason at all is to ignore the investment of time that the employee has made in the company, the enormous consequences of a job loss in a society in which a job is a source of pride and social acceptance, ${ }^{272}$ and a political economy in which unemployment rates play second fiddle to inflation rates. Employment-at-will may also hinder productivity by turning employees into automatons who are afraid to make useful suggestions for changing workplace practices. ${ }^{273}$ The unrepentant protectionists would therefore support legislation that repeals the employment-at-will doctrine by denying employers the right to fire certain long-term employees without good cause. ${ }^{274}$

270 See Marion Crain, Rationalizing Inequality: An Antifeminist Defense of the "Free" Market-A Review of Forbidden Grounds: The Case Against Employment Discrimination Laws, 61 Geo Wash L Rev 556, 562-68 (1993).

${ }^{271}$ See Getman and Kohler, 92 Yale L J at 1421-22 (cited in note 94) (arguing that it is not useful to view bargaining over the terms and conditions of employment as if it consisted of a single individual dealing with another when, in the absence of collective bargaining, it is in reality a single individual dealing with the economic power of a corporate entity); Schwab, 92 Mich L Rev at 29 (cited in note 110).

${ }^{272}$ See Beermann and Singer, $23 \mathrm{Ga} \mathrm{L} \mathrm{Rev} \mathrm{at} \mathrm{917,} \mathrm{929-31} \mathrm{(cited} \mathrm{in} \mathrm{note} \mathrm{110);} \mathrm{Mary}$ Ann Glendon and Edward R. Lev, Changes in the Bonding of the Employment Relationship: An Essay on the New Property, 20 BC L Rev 457, 483 (1979).

273 See Beermann and Singer, $23 \mathrm{Ga} \mathrm{L} \mathrm{Rev} \mathrm{at} 928$ (cited in note 110).

274 See, for example, Clyde W. Summers, Individual Protection Against Unjust Dismissal: Time for a Statute, 62 Va L Rev 481, 519-32 (1976) (proposing a statute). Although the suggestions vary, such laws would at their core empower employees who are about to be fired to demand a hearing before a neutral decision maker (such as an administrative law judge or an independent arbitrator) and would require the employer to establish that it had good cause to terminate the employment relationship. See Estlund, 74 Tex L Rev at 
Also high on the unrepentant protectionist agenda is the goal of eliminating the embeddedness of race and sex discrimination in the workplace. ${ }^{275}$ Real world stories of the lives of people who regularly suffer the indignities of invidious discrimination belie the benign reassurances of the free marketeers that market forces will bring about the gradual "withering away" of invidious race and sex discrimination. ${ }^{276}$ Unrepentant protectionists contend that the radical anti-interventionists' claims that biological differences justify employer use of sex as an efficient sorting mechanism are morally and practically wrong. ${ }^{277}$ Even assuming that laws requiring employers to accommodate people with disabilities operate in practice to redistribute wealth from consumers and shareholders to the disabled, they contend that a society in which people with disabilities may participate productively is worth the cost in lost allocative efficiency. ${ }^{278}$ Troubled by the prospect of a highly differentiated and increasingly hostile society, they believe that government prohibition of employment discrimination will foster greater communication and understanding among people of different races, religions, sexual preferences, and so on. ${ }^{279}$

For the unrepentant protectionist, inequality of bargaining power also explains why information and bargaining alone can-

1682-86 (cited in note 6); Alan Hyde, Endangered Species, 91 Colum L Rev 456, 460-61 \& n 15 (1991).

275 See Dowd, $34 \mathrm{Wm} \&$ Mary L Rev at 481 (cited in note 259).

276 See, for example, Bell, Faces at the Bottom of the Well at 65-66 (cited in note 156); Taunya Lovell Banks, Two Life Stories: Reflections of One Black Woman Law Professor, 6 Berkeley Women's L J 46, 49-55 (1990-91); Richard Delgado, Storytelling for Oppositionists and Others: A Plea for Narrative, 87 Mich L Rev 2411 (1989); Mari J. Matsuda, Voices of America: Accent, Antidiscrimination Law, and a Jurisprudence for the Last Reconstruction, 100 Yale L J 1329, 1333-48 (1991) (recounting "stories" of discrimination); Vicki Schultz, Telling Stories About Women and Work: Judicial Interpretations of Sex Segregation in the Workplace in Title VII Cases Raising the Lack of Interest Argument, 103 Harv L Rev 1749, 1799-1815 (1990).

In the view of the unrepentant protectionists, the radical anti-interventionists who believe that market forces will cause discrimination to "wither away" simplistically avoid the ubiquitous case in which the person discriminated against is one of a large number of otherwise equally endowed individuals. For example, discrimination against AfricanAmericans in hiring janitors will cost the employer very little in efficiency losses if there are hundreds of white applicants for the position.

${ }_{277}$ Mary E. Becker, Barriers Facing Women in the Wage-Labor Market and the Need for Additional Remedies: A Reply to Fischel and Lazear, 53 U Chi L Rev 934 (1986); Joan C. Williams, Deconstructing Gender, 87 Mich L Rev 797 (1989).

${ }^{278}$ See, for example, Tom Harkin, The Americans with Disabilities Act: Four Years Later-A Commentary on Blanck, 79 Iowa L Rev 935, 935, 939 (1994).

279 See Crain, 61 Geo Wash L Rev at 565 (cited in note 270); Matsuda, 100 Yale L J at 1403-06 (cited in note 276). 
not yield the right amount of occupational safety and health protection. For most dangerous industrial jobs, the annualized costs of significant workplace protections are much greater than any individual employee's salary. Thus, it is utterly naive to suggest that migrant field workers or nonunion minimum wage laborers can obtain adequate health and safety protections through individual negotiations over the terms and conditions of employment. Furthermore, these employees are part of a group that does not have the option to vote with their feet by choosing safer jobs.

In the areas of both occupational health and pollution control, the unrepentant protectionists distinguish between two basic approaches to attaining overall goals: (1) identifying some measurable indicia of adequate protection (or acceptable risk of harm) and requiring (or inducing) regulatees to take whatever measures are necessary to achieve that level of protection; and (2) identifying the protective measures that are available and requiring (or inducing) regulatees to adopt such measures (or equivalent measures) without regard to whether those measures by themselves will achieve an adequate level of protection. ${ }^{280}$ The unrepentant protectionists generally prefer a combination of the two approaches with the media quality approach serving as a backup to the pollution reduction approach. In implementing the first approach (the media quality approach), unrepentant protectionists do not generally demand absolute protection (that is, zero risk of harm), but they do insist on a margin of safety as a hedge against uncertainties and they prefer that cost and feasibility considerations play no role whatsoever in determining the level of adequate protection. ${ }^{281}$ Rejecting as largely irrelevant the free marketeer argument that the second approach (the pollution reduction approach) wastefully requires "technology for technology's sake," the unrepentant protectionists observe that it is a good deal easier to implement and note that the nation's environmental statutes have generally evolved in the direction of greater reliance on that approach. ${ }^{282}$

${ }^{280}$ See McGarity, $46 \mathrm{~L}$ \& Contemp Probs at 162-65 (cited in note 140).

${ }^{281}$ See, for example, Natural Resources Defense Council, Inc. $v$ EPA, 824 F2d 1146, 1152-54 (DC Cir 1987) (en banc) (interpreting meaning of "ample margin of safety" in the context of national emissions standards for hazardous air pollutants).

${ }^{282}$ See Howard Latin, Ideal Versus Real Regulatory Efficiency: Implementation of Uniform Standards and "Fine-Tuning" Regulatory Reforms, 37 Stan L Rev 1267, 1304-31 (1985); McGarity, 46 L \& Contemp Probs at 203, 206-09 (cited in note 140). 
The unrepentant protectionists resent the modern mugwump suggestion that calls for more stringent health and environmental regulations are merely special interest pleadings that must be ignored unless justified by reference to some commonly agreed upon measure of the public interest. ${ }^{283}$ They strongly agree with the modern mugwumps that special interests disproportionately influence public policy, ${ }^{284}$ but they do not agree that representatives of consumer, environmental, civil rights, and other public interest groups are equivalent to lobbyists from the National Association of Manufacturers or the Chamber of Commerce. Furthermore, the mugwumps' devotion to the commonly derived public interest is undermined by their invitation to reviewing courts to graft de minimis exceptions on health and environmental legislation. ${ }^{285}$ To the unrepentant protectionist, this suggests that the reviewing judge may substitute his or her own policy preferences for those of the legislature upon concluding that a duly deliberative legislature could not possibly have enacted the statute. This arrogates far too much power to the unelected judiciary and, by implication, to the "great men" who opine in neutral-sounding terms about the substantive principles that should guide the exercise of governmental power.

5. Respect for uncertainty and rejection of cost-benefit analysis.

The unrepentant protectionists have a healthy respect for uncertainty and a corresponding distrust of cost-benefit analysis. ${ }^{286}$ Recognizing that quantitative risk assessment can assist agencies in establishing priorities, the unrepentant protectionists believe that too many uncertainties becloud existing risk-assessment models to recommend them as tools for use in establishing

283 See Sunstein, 48 Stan L Rev at 267 (cited in note 11) (describing two classic battles over environmental policy as "interest-group maneuvering").

${ }^{284}$ See Greider, Who Will Tell the People at 141-58 (cited in note 24).

${ }_{285}$ Sunstein, 97 Yale L J at 1583 (cited in note 162).

${ }^{286}$ See National Research Council, Risk Assessment in the Federal Government: Managing the Process 11-12 (National Academy 1983) ("The dominant analytic difficulty [in agency decisions] is pervasive uncertainty."); John S. Applegate, The Perils of Unreasonable Risk: Information, Regulatory Policy, and Toxic Substances Control, 91 Colum I Rev 261, 264-66 (1991); Sanford E. Gaines, Science, Politics, and the Management of Toxic Risks Through Law, 30 Jurimet J 271, 276-91 (1990); Howard Latin, Good Science, Bad Regulation, and Toxic Risk Assessment, 5 Yale J Reg 89, 147-48 (1988) (noting that cost-benefit analysis is "fundamentally dependent on the quality of regulatory risk assessments"); James P. Leape, Quantitative Risk Assessment in Regulation of Environmental Carcinogens, 4 Harv Envir L Rev 86, 100-103 (1980). 
de minimis levels of risk or in undertaking quantitative costbenefit analysis. First, policy plays a large role in determining the assumptions and inferences that go into mathematical representations of reality. Professional practitioners of risk assessment tend to "dwarf soft variables" like emotional distress and concern for well-being of endangered species. ${ }^{287}$ Unrepentant protectionists particularly object to reductionist attempts to assign a dollar value to the benefits of environmental regulation, such as the saving of human lives and endangered species. ${ }^{288}$ Furthermore, advocates of replacing "worst case" assumptions with "best case" assumptions are often advancing a hidden agenda of achieving less regulation, rather than better regulation. ${ }^{289}$ Having acknowledged uncertainty, unrepentant protectionists remain suspicious of comparative risk assessment as a vehicle for putting particular regulatory initiatives in perspective. ${ }^{290}$ Finally, because risk assessment is generally inaccessible to ordinary citizens, the unrepentant protectionists bemoan the inclination of free marketeers and modern mugwumps to dismiss the legitimate fears of ordinary people who are actually exposed to risk. $^{291}$ When honestly undertaken, a cost-benefit analysis for a

287 See Laurence H. Tribe, Policy Science: Analysis or Ideology?, 2 Phil \& Pub Aff 66, 95-97 (1972); Richard N.L. Andrews, Cost Benefit Analysis As Regulatory Reform, in Daniel Swartzman, Richard A. Liroff, and Kevin G. Croke, eds, Cost-Benefit Analysis and Environmental Regulations: Politics, Ethics, and Methods 107, 123 (Conservative Found 1982).

${ }^{288}$ See Susan J. Tolchin and Martin Tolchin, Dismantling America: The Rush to Deregulate 128-37 (Houghton Mifflin 1983); J.G.U. Adams, ... and how much for your grandmother, 6 Envir \& Planning 619, 619-25 (1974); Baruch Fischhoff, Cost-Benefit Analysis and the Art of Motorcycle Maintenance, 8 Policy Sciences 177, 185-87 (1977); Steven Kelman, Cost Benefit Analysis and Environmental, Safety, and Health Regulation: Ethical and Philosophical Considerations, in Daniel Swartzman, Richard A. Liroff, and Kevin G. Croke, eds, Cost-Benefit Analysis and Environmental Regulations: Politics, Ethics, and Methods 137, 140 (Conservative Found 1982). See also Herbert Hovenkamp, Legislation, Well-Being, and Public Choice, 57 U Chi L Rev 63, 68-73 (1990) (criticizing the Kaldor-Hicks measure of allocative efficiency).

289 See, for example, Latin, 5 Yale J Reg at 93 (cited in note 286) ("The illusion that risk assessment is a purely scientific activity reduces the visibility and political accountability of policy judgments . ..."); National Research Council, Risk Assessment at 33-37 (cited in note 286) (identifying more than forty decision points in a typical risk assessment at which the risk assessor must exercise some degree of scientific judgment); Thomas O. McGarity, Substantive and Procedural Discretion in Administrative Resolution of Science Policy Questions: Regulating Carcinogens in EPA and OSHA, 67 Georgetown L $J$ 729, 793-96 (1979) (noting that agency decisions are often political rather than scientific).

${ }_{290}$ See Donald T. Hornstein, Reclaiming Environmental Law: A Normative Critique of Comparative Risk Analysis, 92 Colum L Rev 562, 563-65, 629-33 (1992).

${ }_{291}$ See David Bollier and Joan Claybrook, Freedom From Harm: The Civilizing Influence of Health, Safety and Environmental Regulation 200-01 (Public Citizen \& Democracy 
complex rule making can at best present a range of alternatives, any one of which might or might not pass the cost-benefit test.

The unrepentant protectionists also believe that cost-benefit analysis is deaf to distributional considerations. The differential impact that a regulation can have on different age groups and on the rich and poor are irrelevant to a cost-benefit analysis of that regulation. ${ }^{292}$ Yet distributional concerns are precisely what have inspired Congress to enact the protections afforded by the civil rights laws and to establish stringent media quality standards to protect sensitive populations. ${ }^{293}$ The unrepentant protectionists complain that cost-benefit analysis can make regulatory actions based primarily upon distributional considerations appear irrational and thereby provide a basis for avoiding their implementation. ${ }^{294}$

The unrepentant protectionists reject the free marketeers' contention that protections that fail to meet the cost-benefit criterion may perversely provide fewer protections than less stringent protections that do meet the cost-benefit test. ${ }^{295}$ This thesis was severely undermined by the fate of OSHA's ambitious attempt to promulgate "lite" standards for about four hundred air contaminants in the late 1980s. Although OSHA consciously attempted to write standards that nearly all regulatees were capable of achieving at little additional cost, the standards were still challenged in court, and therefore were never implemented. ${ }^{296}$

Project 1986).

${ }_{202}$ See, for example, James W. Vaupel, On the Benefits of Health and Safety Regulation, in Allen R. Ferguson and Phillip LeVeen, eds, The Benefits of Health and Safety Regulation 2, 19 (Ballinger 1981) (Society spends more on saving the life and limb of the wealthy and well educated.); Henry M. Peskin, Environmental Policy and the Distribution of Benefits and Costs, in Paul R. Portney, et al, eds, Current Issues in US Environmental Policy 144, 144 (Johns Hopkins 1978) ("Regardless of the total benefits and costs . . . some parties will gain while others lose.").

${ }^{293}$ See Lead Industries Association, Inc. v EPA, 647 F2d 1130, 1152 (DC Cir 1980) (EPA interprets Clean Air Act to provide for protection of sensitive subpopulations in setting national primary ambient air quality standards.).

${ }^{294}$ See Greider, Who Will Tell the People at 56-57 (cited in note 24).

295 See text accompanying notes 146-47.

296 The Eleventh Circuit Court of Appeals unceremoniously remanded the standard to the agency, including in that remand all of the contaminants subject to the standard, whether or not they were challenged. AFL-CIO v OSHA, 965 F2d 962, 986-87 (11th Cir 1992). See generally McGarity and Shapiro, Workers at Risk at 268-77 (cited in note 55) (criticizing argument that OSHA "overregulates" because its employee protections cannot meet a cost-benefit test). 


\section{Fear of ossification.}

Although the unrepentant protectionists are not opposed in principle to sound analysis of regulatory problems, they fear that many of the cognitive regulatory reforms that the free marketeers, the modern mugwumps, and the good government reinventionists advocate will lead to "paralysis by analysis." Quantitative risk assessments and careful cost and economic-impact projections are time consuming and expensive. ${ }^{297}$ Because they always contain debatable assumptions and inferences, they are ripe for criticism at the interagency and judicial review stages. Therefore, agencies feel obliged to include careful discussions of all such assumptions and inferences and to back up factual conclusions with the most recent data. The unrepentant protectionists believe that cognitive regulatory reforms have contributed to the "ossification" of the informal rule-making process. ${ }^{298}$ Pointing out that it is now virtually impossible for even well endowed agencies to promulgate more than a dozen major rules in a single year, they oppose new cognitive regulatory reforms that would impose even more detailed regulatory impact assessment requirements. ${ }^{299}$

\section{Skepticism about market-oriented approaches.}

The unrepentant protectionists are not opposed in principle to market-oriented approaches to achieving nonutilitarian regulatory goals. They are, however, skeptical about the efficacy of market-based regulatory tools in practice. First, they worry that because the protections that many regulatory agencies provide defy easy measurement, the flexibility inherent in market-based approaches will ensure that the underlying regulatory goals are not in fact achieved. ${ }^{300}$ In the air pollution context, for example,

297 See McGarity, Reinventing Rationality at 140-41 (cited in note 37) (tables detailing the costs of preparing regulatory impact analyses).

${ }^{298}$ See Thomas O. McGarity, Some Thoughts on "Deossifying" the Rulemaking Process, 41 Duke L J 1385, 1400-03 (1992).

${ }_{299}$ See Regulatory Reform Act of 1995, Hearings on S 343 before the Subcommittee on Courts and Administrative Practice of the Senate Committee on the Judiciary, 104th Cong, 1st Sess (Feb 22, 1995) (statement of David C. Vladeck, Director of Public Citizen Litigation Group); Job Creation and Wage Enforcement Act of 1995, Hearings on HR 9 before the Subcommittee on Health and Environment and the Subcommittee on Commerce, Trade, and Hazardous Materials of the House Committee on Commerce, 104th Cong, 1st Sess 171 (Feb 1, 1995) (statement of Ellen Silbergeld, Environmental Defense Fund).

${ }^{300}$ See Howard Latin, Ideal Versus Real Regulatory Efficiency: Implementation of Uniform Standards and "Fine-Tuning" Regulatory Reforms, 37 Stan L Rev 1267, 1275-84 (1985). 
modeling inaccuracies and administrative constraints sometimes result in trades that create "hot spots," or localized areas where the media quality targets are exceeded. ${ }^{301}$ In addition, many market-oriented regulatory techniques are not sufficiently enforceable to prevent rampant cheating. ${ }^{302}$ Moreover, a regulatory regime based upon tradable permits may be difficult to adjust in light of new information or changed conditions. If the regulatory entity overestimates the number of marketable permits required to meet the goal, it may be very difficult to withdraw or devalue existing permits once companies have gone to the expense of purchasing them. ${ }^{303}$ Finally, as previously discussed, the unrepentant protectionists are concerned that some marketbased approaches send the wrong symbolic messages to the citizenry. ${ }^{304}$

\section{Cynicism about consensual and voluntary approaches.}

The unrepentant protectionists are dubious about the efficacy of the deliberative models offered by the modern mugwumps and the voluntary approaches applauded by the good government reinventionists. The idea of political equality in a "deliberative democracy" that lies at the heart of modern civic republicanism is a noble sentiment, but there is considerable tension between it and the modern mugwump rejection of egalitarianism in the private sector and their advocacy of a robust role for the institution of private property. To suppose that there can be true equality of citizen participation in the political arena when there are huge disparities of wealth in the private sector may be naive. ${ }^{305}$

301 See Barry M. Mitnick, The Political Economy of Regulation: Creating, Designing, and Removing Regulatory Forms 394 (Columbia 1980). See also Stewart, 9 Harv Envir L Rev at 15-16 (cited in note 155).

${ }^{302}$ See Mitnick, Political Economy at 395 (cited in note 301) (suggesting that cheating may be easier in a pollution permit regime than in one that uses pollution charges); Errol Meidinger, On Explaining the Development of 'Emissions Trading' in U.S. Air Pollution Regulation, 7 L \& Policy 447, 461 (1985) (arguing that market mechanisms will be hard to administer and may result in "innovations in evasion").

${ }^{303}$ Meidinger, $7 \mathrm{~L} \&$ Policy at 470 (cited in note 302); Lettie M. Wenner, The Environmental Decade in Court 53 (Indiana 1982).

${ }^{304}$ See text accompanying notes 260-61.

${ }^{305}$ See Seidenfeld, 105 Harv I Rev at 1537 (cited in note 174). In the context of complex informal rule making, for example, the civic republican ideal of deliberative democracy suggests that all affected entities should first reach a consensus about the policies that guide the assumptions and inferences that are put into the quantitative analysis. But who has the time to study the issues with the care needed to separate the science from the policy? Only the citizens with an intense interest in the outcome and the money to hire experts to aid them in the effort. The nature of the governmental activity thus 
The belief in the potential for consensus that also lies at the core of the modern mugwump view may likewise be ill founded. The beneficiaries of existing environmental, consumer, and labor legislation chuckle at the prospect of a reasoned empathetic dialogue with the disciples of Newt Gingrich who believe that politics is war without guns. They worry that the modern mugwump search for consensus about fundamental principles will necessarily be limited to the perspectives of an elite group of societal decision makers who, however gamely they strive to place civic virtue over self-interest, are at least partially blind to the perspectives of people who are not like them. ${ }^{306}$ When the rich and powerful find themselves in a minority, which will often be the case in debates over protective regulation, they will dissent loudly in a fashion that cannot be ignored. ${ }^{307}$ The unrepentant protectionists fear that the modern mugwump demand for consensus will become a one-way street in which only deregulatory action can go forward.

When they read of the good government reinventionists' concern for government's customers, the unrepentant protectionists sometimes wonder who the customers really are. At first glance, it would seem that the consumers of a regulatory program are the citizens that the agency's rules and regulations were intended to protect. The reinvention rhetoric, however, often suggests that its proponents in the government see their consumers as the industries from whom the regulatory beneficiaries are seeking protection. ${ }^{308}$ The unrepentant protectionists are therefore leery of voluntary approaches toward protecting the powerless from the powerful. The good government reinventionist suggestion that greater reliance be placed on joint worker-management committees, for example, may increase worker satisfaction and productivity, but it may also facilitate employer domination

creates a tension between deliberation and equality.

${ }^{306}$ See Beermann and Singer, $23 \mathrm{Ga} \mathrm{L} \mathrm{Rev} \mathrm{at} 913$ (cited in note 110); Eskridge and Peller, 89 Mich L Rev at 790 (cited in note 167).

${ }^{307}$ Greider, Who Will Tell the People at 51-52 (cited in note 24).

${ }^{308}$ For example, most of the EPA's touted voluntary reinvention efforts are designed to reduce regulatory burdens. Gore, Common Sense Government at 37-39 (cited in note 78). See United States General Accounting Office, Pub No GAO/T-GGD-95-206, Regulatory Reform: How Can Congress Assess the Administration's Initiatives? 1 (1995) (statement of L. Nye Stevens, Director, Federal Management and Workforce Issues, concluding that the two central themes of the Clinton administration's reinvention initiatives are: "(1) an attempt to reduce the burden federal regulations and regulatory agencies impose on the regulated public and (2) an attempt to change agencies' regulatory approach from a focus on compliance with detailed procedures to a focus on achieving outcomes"). 
of workers. ${ }^{309}$ So long as the employer appears to be considering employee claims seriously, it may not have to sacrifice any real power. It is not clear why the government would be any more effective in ensuring that such committees are legitimate than it is in ensuring that workers are not fired for favoring a union. ${ }^{310}$

The unrepentant protectionists note that most of the "voluntary" programs advocated by the good government reinventionists involve incentives designed to induce conduct that the agency is powerless to compel. There is a very real danger, however, that the government will give away more than it gains. For example, when OSHA agreed in the early 1980s to reduce the frequency of inspections for workplaces that voluntarily achieved below-average workplace injury rates, one predictable result was a rash of underreporting of workplace accidents. ${ }^{311}$ If the net result of the program was to induce employers to hide, rather than prevent, accidents, then the statute's worker protection goals were seriously undermined by the voluntary program.

\section{Distrust of centralized management of bureaucracies.}

The unrepentant protectionists are suspicious of centralized management of the regulatory agencies, not so much out of a conviction that centralized management is undesirable in principle as out of the unpleasant experience of having seen that process abused by previous administrations. In the past, centralized review has provided an opportunity for regulatees ex parte to arm OMB reviewers with arguments for changing the substance of draft rules before they are published in the Federal Register. ${ }^{312}$ Central reviewers have also urged agencies to adopt policy positions that run directly counter to their statutory missions. ${ }^{313}$ Even when not used for sinister purposes, centralized review provides yet another opportunity to delay the rule-making

${ }^{309}$ See Hyde, 91 Colum I Rev at 466 (cited in note 274).

310 See Matthew W. Finkin, Back to the Future of Labor Law, 32 Wm \& Mary L Rev 1005, 1018-19, 1024-25 (1991).

311 McGarity and Shapiro, Workers at Risk at ch 10 (cited in note 55).

312 See id at 141-48, 154. See also Erik D. Olson, The Quiet Shift of Power: Office of Management \& Budget Supervision of Environmental Protection Agency Rulemaking under Executive Order 12,291, 4 Va J Natural Resources L 1, 28-35, 55-57 (1984); William F. West and Joseph Cooper, Legislative Influence v. Presidential Dominance: Competing Models of Bureaucratic Control, 104 Pol Science Q 581, 596-97 (1989).

${ }^{313}$ See Oliver A. Houck, President $X$ and the New (Approved) Decisionmaking, 36 Am U L Rev 535, 537-38 (1987). See also Louis L. Jaffe, Invective and Investigation in Administrative Law, 52 Harv L Rev 1201, 1238-39 (1939) (criticizing an early presidential push to centralize control of independent agencies). 
process interminably. ${ }^{314}$ The unrepentant protectionists therefore oppose structural regulatory reforms aimed at creating a permanent institutional arrangement for centralized review.

\section{Distaste for devolution.}

The unrepentant protectionists have an inherent distaste for structural reforms that result in greater devolution of regulatory authority to states and localities. They note that nearly all of the federal protections that Congress crafted resulted from long and painful experience with ineffective state-administered programs. ${ }^{315}$ The efforts of southern (and many northern) states to protect minorities from irrational discrimination had failed for a century following the Civil War before Congress finally concluded that federal intervention into private market arrangements was necessary. Under state stewardship, the air and surface waters of the United States were allowed to deteriorate to unconscionable levels before Congress stepped in and enacted the modern pollution control statutes. ${ }^{316}$ The carnage in the workplace that lay in the wake of decades of experience with weak and poorly enforced state worker-protection statutes prompted Congress to create OSHA. The unrepentant protectionists believe that those who would now have these vital protective programs devolve to the states should shoulder the burden of demonstrating that the states will be more capable than they have proved to be during the first two-thirds of the twentieth century. More specifically, these would-be reformers must demonstrate that the states will not succumb to the temptation to "race to the bottom" in order to attract or retain politically powerful businesses.

314 See McGarity, Reinventing Rationality at 237 (cited in note 37); McGarity and Shapiro, Workers at Risk at ch 15 (cited in note 55); Tolchin and Tolchin, Dismantling America: The Rush to Deregulate at $41-42$ (cited in note 288) (FDA official says that probusiness Reagan administration brought things to a "snail's pace" with requests for additional information.).

315 See Gore, Common Sense Government at 15 (cited in note 78) (reporting that "a wide array of issues-pollution, poverty, and racial injustice, to name a few-became federal responsibilities because they could not be solved by states acting on their own").

${ }^{316}$ See Alfred C. Aman, Jr., Administrative Law in a Global Era: Progress, Deregulatory Change, and the Rise of the Administrative Presidency, 73 Cornell $\mathrm{L}$ Rev 1101, 1194 (1988); Susan Bartlett Foote, Administrative Preemption: An Experiment in Regulatory Federalism, 70 Va L Rev 1429, 1433-34 (1984). 


\section{FUTURE DIRECTIONS}

If the regulatory state does in fact stand at a crossroads, it is appropriate to speculate about the direction that it will take in the future. At least four scenarios are plausible.

\section{A. The Radical Relief Scenario}

The radical anti-interventionists' agenda for the 104th Congress includes enactment of important omnibus regulatory reform legislation, generic property rights legislation, and substantial amendments to, or repeals of, existing protective statutes. The "Contract with America" promised the first two reforms, and legislation aimed at accomplishing the third was introduced in the House of Representatives soon after it was called to order. ${ }^{317}$ The House of Representatives has passed a radical regulatory reform bill ${ }^{318}$ that, among other things, would: make costbenefit analysis a decisional criterion for all major rules; define the term "major" to include a vastly greater number of regulations than in the past; subject existing major rules to reexamination under the new decisional criterion; require detailed regulatory analyses and peer review for major rules; entitle landowners to compensation for specified governmental actions that diminish property values by twenty percent; and subject all of the analyses and substantive decisions to judicial review. ${ }^{319}$ The House has also passed amendments to the Clean Water Act that would radically limit the scope and focus of that statute, ${ }^{320}$ and the House is seriously considering radical amendments to the Occupational Safety and Health Act that would assign to OSHA a largely consultative role. ${ }^{321}$

${ }^{317}$ See Gillespie and Schellhas, eds, Contract with America at 126-28 (cited in note 79); Job Creation and Wage Enhancement Act of 1995, HR 9, 104th Cong, 1st Sess (Jan 4, 1995), in 141 Cong Rec H124 (Jan 5, 1995); HR 961, 104th Cong, 1st Sess (Feb 15, 1995), in 141 Cong Rec H1849 (Feb 15, 1995) (comprehensive amendments to Clean Water Act); HR 479, 104th Cong, 1st Sess (Jan 11, 1995), in 141 Cong Rec H229 (Jan 11, 1995) (bill introduced by House Majority Whip Tom DeLay calling for repeal of Clean Air Act Amendments of 1990); Regulatory Transition Act of 1995, HR 450, 104th Cong, 1st Sess (Jan 9, 1995), in 141 Cong Rec H157-58 (Jan 9, 1995) (calling for a moratorium on new listings of endangered species and designation of critical habitat).

318141 Cong Rec H2618-19 (Mar 3, 1995).

319 HR 9 \$§ 203, 402(3), 421-24, 431, 441 (cited in note 82).

320 HR 961, 104th Cong, 1st Sess (May 16, 1995), in 141 Cong Rec H5013 (May 16, 1995).

${ }^{321}$ See Ballenger Bill Would Refocus OSHA Mission to Consultative Efforts, Daily Labor Rep (BNA) A-14, A-14 to A-15 (June 15, 1995); Ballenger Bill Would Limit OSHA, Merge It With MSHA, Natl J Cong Daily 4 (June 14, 1995). 
Although the momentum for radical reforms has remained strong in the House, it has diminished considerably in the more deliberative Senate. After struggling for months to come up with an omnibus regulatory reform bill that would survive a cloture vote, the Senate Republican leadership gave up, and it is entirely possible that no omnibus regulatory reform legislation will emerge from the 104th Congress. ${ }^{322}$

Furthermore, there is evidence that the radical anti-interventionists have already pushed the agenda beyond the considerable tolerance of thoughtful citizens who vote in elections and write their congresspersons. ${ }^{323}$ In part because of the media coverage that the House leadership invited, the unrepentant protectionists and their allies in Congress received a highly visible forum for their arguments that the Contract with America was a reactionary call for a return to a world in which private entrepreneurs are free to dictate the conditions of employment, the country's natural resources are easily available for private exploitation, and vast private accumulations of wealth mock the devastating poverty of those who do not hop aboard the fast train to prosperity.

Although the unrepentant protectionists and the good government reinventionists have so far successfully fought rearguard battles in Congress, if they are unable to translate the defensive legislative victories of 1995 into electoral votes in 1996, the regulatory state is in for some profound changes.

322 The House passed HR 9 on March 3, 1995. 141 Cong Rec H2639 (Mar 3, 1995). After weeks of debate in mid-June and July 1995, the Senate very nearly passed a version of $S 343$. That bill represented a compromise between the version of $S 343$ reported out of the Senate Judiciary Committee, a somewhat less comprehensive bill (S 333) reported out of the Senate Energy and Natural Resources Committee, and a more moderate bill (S 291) reported out of the Senate Governmental Affairs Committee. See John Sullivan, Committee Work on Rules Relief Done, Attention Turns to Crafting a Floor Bill, Daily Labor Rep (BNA) A-13, A-13 to A-14 (May 2, 1995). As S 343 neared floor consideration, it was amended on two more occasions (without the benefit of committee hearings) by the staffs of Senator Dole and Senator Bennett Johnston in an effort to produce a bill that both Republicans and conservative Democrats could support so as to pretermit any possible filibuster. See Dole, Johnston Reach Senate Regulatory Reform Deal, Natl J Cong Daily 1, 1 (June 22, 1995); Johnston, Dole Reach Tentative Agreement on New Senate Regulatory Reform Package, Daily Rep Exec (BNA) A34 (June 21, 1995).

${ }_{323}$ See Richard L. Berke, The Mellowing of the American Voter, NY Times Section 4 at 1, 4 (Jan 7, 1996); Sunstein, 48 Stan I Rev at 250 (cited in note 11) (acknowledging that the public has not (yet) accepted the radical anti-interventionist agenda). 


\section{B. The Gridlock Scenario}

Another plausible scenario is a sustained impasse in which the good government reinventionists win the initial battles against the radical anti-interventionists and the free marketeers, and the political heat generated by the anti-interventionists slowly dissipates. The Clinton administration is filled with good government reinventionists who control much of the federal bureaucracy. In this scenario, protective legislation will periodically come up for reauthorization, but the President (be it Clinton or Gore) will threaten to veto any congressional attempts to replace existing statutes with radically different regulatory frameworks. Unless the electorate sends Republicans to Congress in even greater numbers than it did in 1994, the prospects for overriding those vetoes are not very high. The result could be a sustained gridlock during which very little new legislation is enacted, reduced agency budgets preclude effective enforcement of existing regulations, and the executive branch continues to experiment with consensual and voluntary techniques for protecting regulatory beneficiaries.

\section{The Free Market Scenario}

It is possible that as the pendulum begins its swing back toward further protections, the modern mugwumps will have their day in the sun: Congress will enact less radical legislation that accomplishes some reform, but is still palatable to President Clinton and moderate Democrats. Congress could enact "reasonable" reforms providing for greater use of performance standards and market incentives with a decisional criterion that allows, but does not require, agencies to employ cost-benefit analysis in writing regulations. The legislation might even incorporate some modern mugwump elements such as broader opportunities for public participation and prohibitions on ex parte contacts with OMB.

It may well be, however, that the mugwump belief in the middle ground is untenable. This scenario presumes a broad middle ground of public opinion that can be energized by presbyterian appeals to moderation and civic virtue. However, the years since the end of the Vietnam War may have so polarized the citizenry that there is no middle America to be won over. In a political milieu in which negative campaigning is the order of the day and public cynicism about what motivates politicians seems deeper than ever, modern mugwump appeals to civility in public 
discourse may be welcome, but irrelevant. The modern mugwumps face a dilemma in that their substantive solutions cannot command anything like a consensus among the affected interests. As a result, they play the undesirable role of apologist for substantive policies that advance the partisan agendas of the radical anti-interventionists and free marketeers.

\section{The Revived Regulation Scenario}

Although we are probably not in the midst of a transformative constitutional moment, the short-term prognosis for protective regulation in American society is as poor as it has been since the end of the New Deal. While it is always possible that some traumatic event or steep economic downturn will allow the unrepentant protectionists to assume the offensive, Congress is not likely to enact significant protectionist statutes during the next decade. The prospects for a revived regulation scenario are probably highest if the radical relief scenario first plays itself out. Congress may be willing to contemplate enacting additional protections only after a period of time in which the radical antiinterventionists and free marketeers have their way: the existing protective statutes are repealed or undermined, the free market reigns supreme, the consequences of unrestrained capitalism become increasingly apparent, and pressures build to remedy the most egregious abuses. It may, in other words, take another tragedy like the Great Depression to revive the conviction that government has an important protective role to play in private arrangements.

\section{CONCLUSION}

Of the scenarios outlined above, the second and third are the most probable. Both the radical relief scenario and the revived regulation scenario include a definitive victory for the radical anti-interventionists and the free marketeers, and this would probably require that the Republicans both retake the White House and build on the electoral successes of 1994 in Congress. While neither outcome is beyond the realm of possibility, the combination is not very likely. Whether gridlock will prevail or moderate market-based legislation will be enacted depends upon a number of factors. If the hard-line anti-interventionists refuse to budge or if the unrepentant protectionists are especially persuasive, gridlock will continue into the foreseeable future. If, however, most members of Congress become persuaded that 
there is a large constituency for middle-ground solutions, then a viable, but much less protective, regulatory state may emerge from this particular crossroads. 